\title{
GO/PAMAM as a High Capacity Adsorbent for Removal of Alizarin Red S: Selective Separation of Dyes
}

\author{
Mohammad Rafi, ${ }^{1}$ Babak Samiey ${ }^{1, *}$ and Chil-Hung Cheng ${ }^{2}$ \\ ${ }^{1}$ Department of Chemistry, Faculty of Science, Lorestan University, Khoramabad 68137-17133, Lorestan, Iran \\ ${ }^{2}$ Department of Chemical Engineering, Ryerson University, M5B 2K3, Toronto, Ontario, Canada \\ *Corresponding author: E-mail: babsamiey@yahoo.com, samiey.b@lu.ac.ir
}

Received: 03-16-2020

\begin{abstract}
Adsorption of Alizarin Red S (ARS) on graphene oxide/poly(amidoamine) (GO/PAMAM) was studied at different ARS initial concentrations, temperatures, $\mathrm{pHs}$, shaking rates and contact times. Adsorption sites of GO/PAMAM were phenolic $-\mathrm{OH}(\mathrm{Ph})$ group of $\mathrm{GO}$ and amine groups $\left(-\mathrm{NH}_{2},-\mathrm{NH}^{+}{ }_{3}\right.$ and $\left.-\mathrm{NHR}^{+}\right)$of PAMAM dendrimer moieties of $\mathrm{GO} /$ PAMAM. At $\mathrm{pH}=2$ and $318 \mathrm{~K}$, maximum adsorption capacity $\left(q_{e, \max }\right)$ of the adsorbent was $1275.2 \mathrm{mg} \mathrm{g}^{-1}$ which is one of the highest capacity in the literature. Thus, GO/PAMAM in this work acted as a superadsorbent for ARS. At the incipient of adsorption, $A R S^{-}$molecules were adsorbed on $P h$ sites that was reaction-controlled step, $\left(\mathrm{E}_{\mathrm{a}}=114.5 \mathrm{~kJ}\right.$ $\mathrm{mol}^{-1}$ ). Adsorption of $A R S^{-}$on the remaining sites was diffusion-controlled. In alkaline media, two other types of ARS molecules were identified during that were adsorbed on $\mathrm{Ph}$ and $-\mathrm{NH}^{+}{ }_{3}$ sites. Further increasing the $\mathrm{pH}$ of the solution, decreased the number these two sites and yielded a reduced adsorption capacity $\left(q_{e, \max }\right)$. Methylene blue $(\mathrm{MB})$, thionine (Th), pyronin Y (PY), acridine orange (AO), methyl blue (MEB) and janus green (JG) dyes were selectively separated from their mixtures with ARS molecules using GO/PAMAM at $\mathrm{pH}$ of 2 . The used adsorbent was recycled efficiently by using ethylenediamine very fast.
\end{abstract}

Keywords Alizarin Red S; GO/PAMAM; Adsorption; ARIAN model; KASRA model; ISO equation

\section{Introduction}

Wastewater generated by different industries contains pollutant compounds that are hazardous to the health of human beings and animals. Dye compounds included in these pollutants of wastewater are produced by industries like food, paper, rubber, textile, printing, tanning, dyestuff and pigment industries. During the last decades extensive progress has been made for treatment of industrial wastewaters. A number of techniques used for this purpose are filtration, ${ }^{1}$ chemical oxidation, ${ }^{2}$ ion exchange, ${ }^{3}$ biological degradation, ${ }^{4}$ reverse osmosis, ${ }^{5}$ coagulation, ${ }^{6}$ and adsorption. ${ }^{7}$ Adsorption is a facile, cost effective and widely-applied method to remove dye compounds from wastewater systems and in many cases can be recycled easily.

Alizarin Red S (ARS), sodium 3,4-dihydroxy-9,10-dioxo-9,10-dihydroanthracene-2-sulfonate, is also known as Mordant Red 3 or Alizarin Carmine which is an anthraquinone and anionic dye. ARS is applied as an acid-base indicator, ${ }^{8}$ a red textile dye, ${ }^{9}$ for staining in histology ${ }^{10}$ and as a chromogenic agent for selective spectroscopic determination of some compounds. ${ }^{11}$

For removing ARS from wastewaters, various kinds of adsorbents were used, such as activated carbon $/ \gamma-\mathrm{Fe}_{2} \mathrm{O}_{3}$ nano-composite, ${ }^{12}$ modified nano-sized silica, ${ }^{13}$ magnetic chitosan, ${ }^{14}$ lantana camara, ${ }^{15}$ coconut shell activated carbon, ${ }^{16}$ activated clay modified by iron oxide, ${ }^{17} \mathrm{Fe}_{3} \mathrm{O}_{4} / \mathrm{CeO}_{2}$ nanocomposite, ${ }^{18}$ calcined $[\mathrm{Mg} / \mathrm{Al}, \mathrm{Zn} / \mathrm{Al}$ and $\mathrm{MgZn} / \mathrm{Al}]$ $\mathrm{LDH},{ }^{19}$ nanocrystalline $\mathrm{Cu}_{0.5} \mathrm{Zn}_{0.5} \mathrm{Ce}_{3} \mathrm{O}_{5},{ }^{20}$ activated carbon engrafted with $\mathrm{Ag}$ nanoparticles, ${ }^{21}$ nano- $\mathrm{Fe}_{3} \mathrm{O}_{4}$ and corn cover composite 22 and chitosan/ $\mathrm{ZnO}$ nanorod composite. ${ }^{23}$ The $q_{e, \max }$ value values of these adsorbents are tabulated in Table 1.

In this study, graphene oxide/poly(amidoamine) (GO/PAMAM) was synthesized by grafting poly(amidoamine) (PAMAM) dendrimer to graphene oxide. ${ }^{24-26}$

The as-synthesized GO/PAMAM and ARS-adsorbed GO/PAMAM were characterized by different techniques like BET (Brunauer-Emmett-Teller), SEM (Scanning Electron Microscope), EDS (Energy Dispersive X-Ray Spectroscopy), XRD (X-Ray Diffraction) and FTIR 
Table 1. Maximum adsorption capacity $\left(q_{e, \text { max }}\right)$ of ARS on a series of adsorbents.

\begin{tabular}{|c|c|c|c|}
\hline Adsorbent & $\mathbf{T}(\mathbf{K})$ & $q_{e, \max }\left(\mathbf{m g ~ g}^{-1}\right)$ & Ref. \\
\hline Activated carbon $/ \gamma-\mathrm{Fe} 2 \mathrm{O} 3$ & 298 & 108.7 & 12 \\
\hline Modified nano-sized silica & 293 & 200.0 & 13 \\
\hline Magnetic chitosan & 303 & 40.1 & 14 \\
\hline Activated clay modified by iron oxide & 298 & 32.7 & 17 \\
\hline $\mathrm{Fe}_{3} \mathrm{O}_{4} / \mathrm{CeO}_{2}$ nanocomposite & 303 & 90.5 & 18 \\
\hline Activated carbon engrafted with Ag nanoparticles & 298 & 232.6 & 21 \\
\hline Nano- $\mathrm{Fe}_{3} \mathrm{O}_{4}$ and corn cover composite & 298 & 10.4 & 22 \\
\hline GO/PAMAM & 328 & 1275.2 & This work \\
\hline
\end{tabular}

(Fourier Transform Infrared Spectroscopy) techniques. The adsorption process of ARS on GO/PAMAM surface was carried out under different experimental conditions including ARS concentration, ionic strength, $\mathrm{pH}$, temperature, shaking rate and contact time. Due to high adsorption capacity of GO/PAMAM for ARS, GO/PAMAM was considered as a superadsorbent for ARS dye, Table 1.

Kinetics and thermodynamics of adsorption of ARS on GO/PAMAM surface were investigated using the ARIAN and KASRA models respectively that elucidated the process mechanism. Also, high capacity adsorption of GO/ PAMAM in acidic $\mathrm{pHs}$ for ARS was used for selective separation of a number of dyes from their mixtures with ARS.

\section{Experimental}

\section{1. Chemicals}

Alizarin Red S, alizarin, methylene blue, acridine orange, thionine, pyronin $\mathrm{Y}$, methyl blue, janus green $\mathrm{B}$, sodium hydroxide, sodium chloride, sodium nitrate, potassium permanganate, concentrated sulfuric acid (98\%), hydrochloric acid (37\%), hydrogen peroxide (30\%), methanol ( $\geq 99.9 \%)$, ethanol ( $\geq 99.9 \%)$, ethylenediamine $(\geq 99 \%)$, diethylenetriamine ( $\geq 98 \%)$, methyl acrylate ( $\geq 99 \%), N, N$-dimethylformamide (DMF) $(\geq 99.8 \%)$, tetrahydrofuran (THF) ( $\geq 99 \%)$, acetone $(99.8 \%)$, benzene $(>99 \%)$, dimethylsulfoxide (DMSO) $(\geq 99.9 \%)$ and diethyl ether $(\geq 99.7 \%)$ were purchased from Merck. Graphite powder $(<20 \mu \mathrm{m})(\geq 99.9 \%)$ was purchased from Sigma-Aldrich. All chemicals were used without further purification.

\section{2. Synthesis of GO/PAMAM}

Generation 2 PAMAM (G2 PAMAM) dendrimer (the first generation in this kind of nomenclature is called G-0.5), graphene oxide (GO) and GO/PAMAM were synthesized based on the published procedure. ${ }^{26}$

\section{3. Characterization of GO/PAMAM}

The nitrogen-based BET specific surface area of GO/ PAMAM was determined by a Pore Size Micromet- rics-tristar 3020 instrument, Figure S1. The obtained BET isotherm for GO/PAMAM was type IV and its BET surface area, maximum pore volume (slit pore geometry), adsorption average pore diameter (by BET) and pore volume were $9.59 \mathrm{~m}^{2} \mathrm{~g}^{-1}, 0.0044 \mathrm{~cm}^{3} \mathrm{~g}^{-1}, 18.9 \mathrm{~nm}$ and $0.045 \mathrm{~cm}^{3}$ $\mathrm{g}^{-1}$, respectively. It is noticeable that BET surface and pore volume of GO/PAMAM in this work are several times higher than those of reported. ${ }^{26}$ Also, its hysteresis loop was $\mathrm{H} 3$ which in this case aggregates of platelike $\mathrm{GO} /$ PAMAM nanoparticles form slit-like pores. ${ }^{27}$

Scanning electron micrographs (SEM) of GO/ PAMAM and ARS-adsorbed GO/PAMAM samples at $\mathrm{pHs}$ of 0,2 and 13 were taken using a MIRA3 TESCAN equipment at $15 \mathrm{keV}$. The SEM photos of pristine GO/PAMAM and its samples obtained under different conditions exhibited similar surface morphology which were aggregations of PAMAM-covered particles with a porous morphology, Figures $1(\mathrm{a})-1(\mathrm{~h})$. The average size of GO/PAMAM particles estimated by SEM technique was about $30 \mathrm{~nm}$, Figure S2.

EDS spectrum of the as-synthesized GO/PAMAM was acquired by a MIRA3 TESCAN equipment. According to the results of EDS, the atomic percentages of elements on its surface were similar to the published results ${ }^{26}$ which confirmed the formation of GO/PAMAM, Figure S3. The XRD pattern of as-synthesized GO/PAMAM was recorded by a Rigaku D-max C III, X-ray diffractometer using Ni-filtered $\mathrm{Cu}-\mathrm{Ka}$ radiation $(\lambda=1.5406 \AA)$. The smooth intensity with broad peaks at around $2 \theta$ of $26.7^{\circ}$ showed that the main structure of GO/PAMAM was amorphous, Figure 2(a). The XRD spectrum of GO/ PAMAM was similar to that in the literature. ${ }^{26}$

Also, the FTIR spectrum of GO/PAMAM was taken by a Nicolet IR 100 (Thermo Scientific) FTIR spectrophotometer using $\mathrm{KBr}$ pellet technique, Figure 3(a). The peak at $1185 \mathrm{~cm}^{-1}$ was assigned to the stretching vibration of $\mathrm{C}-\mathrm{OH}$ (phenolic) groups of GO/PAMAM. ${ }^{26,28,29}$ The spectrum was very similar to that of the previous report for GO/PAMAM. ${ }^{26}$ The absence of the peak at $1680-1760$ $\mathrm{cm}^{-1}$ confirmed the lack of carboxylic acid group in $\mathrm{GO} /$ PAMAM. Diminishing the $\mathrm{C}=\mathrm{O}$ band of $\mathrm{GO}$ at $1731 \mathrm{~cm}^{-1}$ and the appearance bands at $1637 \mathrm{~cm}^{-1}(\mathrm{C}=\mathrm{O}$ amide I stretching vibration mode), ${ }^{24,29,30}$ in the IR spectrum of as-synthesized GO/PAMAM confirmed that the GO/ PAMAM was synthesized. 


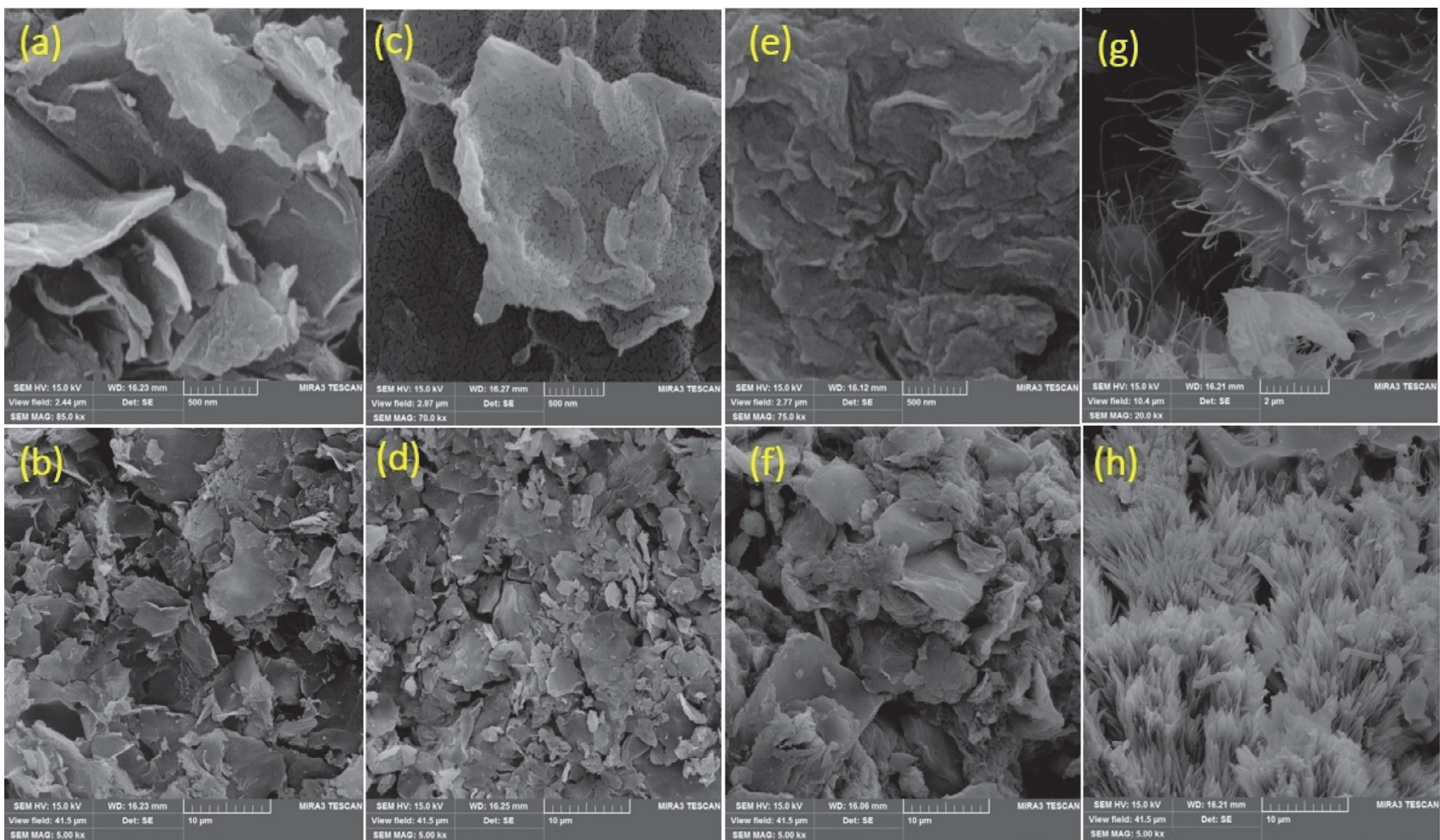

Figure 1. SEM images of $(\mathrm{a}, \mathrm{b})$ pristine GO/PAMAM, $(\mathrm{c}, \mathrm{d}) \mathrm{GO} / \mathrm{PAMAM}$ modified at $\mathrm{pH}=0$ and ARS-adsorbed GO/PAMAM samples at $(\mathrm{e}, \mathrm{f}) \mathrm{pH}=2$ and $(\mathrm{g}, \mathrm{h}) \mathrm{pH}=13$.

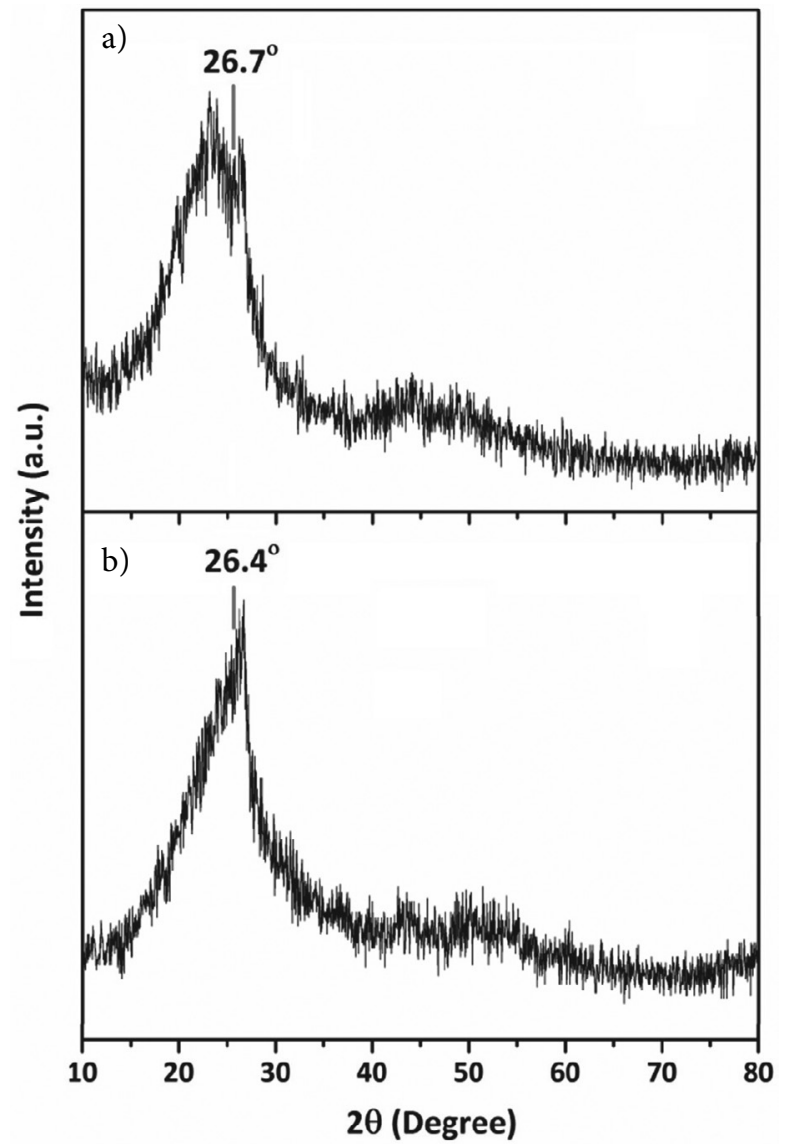

Figure 2. XRD spectra of (a) pristine GO/PAMAM, (b) GO/PAMAM modified at $\mathrm{pH}=0$.

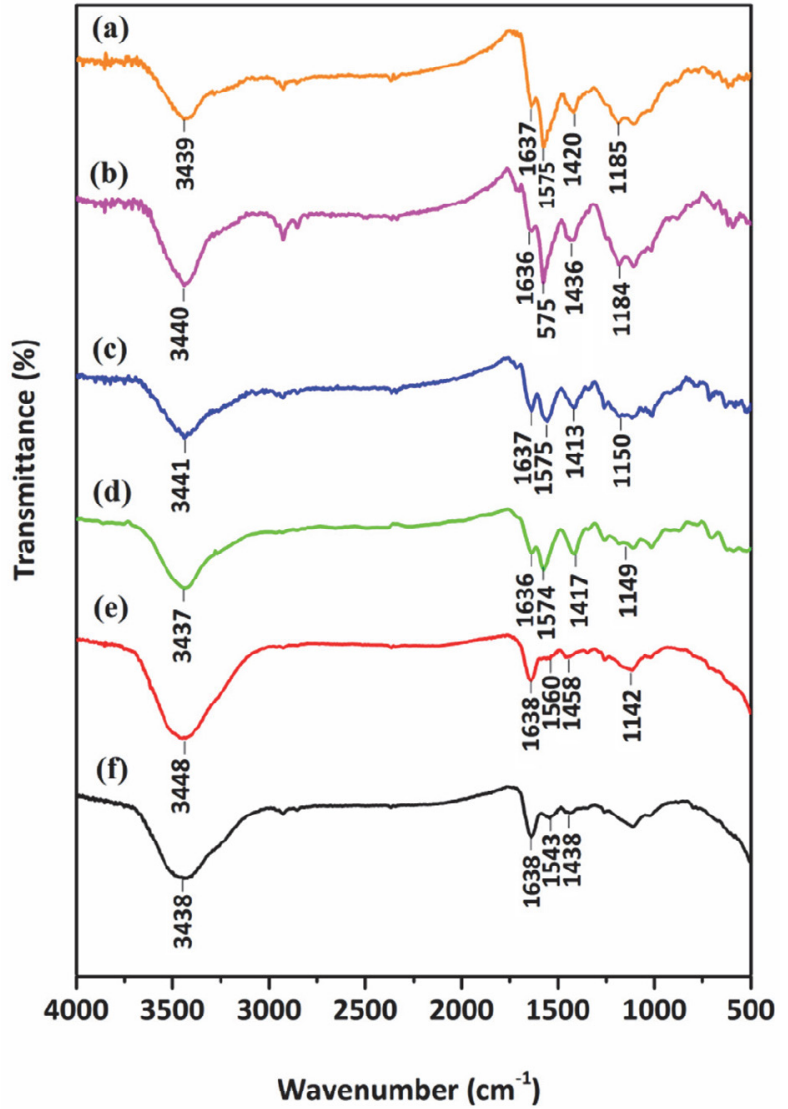

Figure 3. IR spectra of (a) pristine GO/PAMAM, (b) GO/PAMAM modified at $\mathrm{pH}=0$ and $\mathrm{ARS}$-adsorbed $\mathrm{GO} / \mathrm{PAMAM}$ at (c) $\mathrm{pH}=0$, (d) $\mathrm{pH}=2$, (e) $\mathrm{pH}=5$ and (f) $\mathrm{pH}=10$. 
Chemical analysis of pristine GO/PAMAM by a ECS 4010 CHNS-O elemental analyzer showed that this compound contains $17.22 \%$ nitrogen, $64.02 \%$ carbon and $4.39 \%$ hydrogen by mass, Figure S4.

\section{4. Adsorption Experiments, Equations and Models}

Adsorption capacity relation, adsorption experiment details, kinetic and thermodynamic equations and models used for analysis of adsorption experiments and all symbols and abbreviations were explained in detail in Supplementary Materials, Figures S5 and S6. ${ }^{26,32-38}$

\section{Results and Discussion}

\section{1. Thermodynamics of Adsorption of ARS on GO/PAMAM}

The ARS molecule has two $p K_{a}$ values, $p K_{a 1}=5.5$ and $p K_{a 2}=11.5 .{ }^{39,40}$ This compound, under experimental conditions, at $\mathrm{pH} \leq 3$ and $\mathrm{pHs}$ of 11 and 13 was in the forms of $A R S^{-}$(yellow), $A R S^{2-}$ (red) and $A R S^{3-}$ (violet) molecules respectively, Figures $6(\mathrm{a})$ and $6(\mathrm{~b})$. The chemical structure used for $A R S^{-}$was confirmed before. ${ }^{41}$ Thus, there were one or two ARS forms in solutions within the applied $\mathrm{pH}$ range in this work. These ARS forms are potential species in the solution, interacting with GO/PAMAM surface.
As published, ${ }^{29,42}$ protonated primary amine ($\mathrm{NH}_{3}^{+}$), phenolic $-\mathrm{OH}$ and protonated tertiary amine ($\mathrm{NHR}_{2}{ }_{2}$ ) groups of GO/PAMAM started to be deprotonated at pHs higher than 9.54 and 8.24 and 4, respectively. Thus, in acidic solutions these three functional groups and in alkaline media protonated and deprotonated primary amine groups of GO/PAMAM were its probable candidate groups for the adsorption of ARS molecules. Role of the $\mathrm{CO}-\mathrm{NH}$ - (amide) groups of the GO/PAMAM in the adsorption process was studied using FTIR spectra.

The peak of stretching vibration of phenolic $\mathrm{C}-\mathrm{OH}$ group at $1185.5 \mathrm{~cm}^{-1}$ in the IR spectrum of GO/PAMAM, Figure 3(a), shifted to $1149.1 \mathrm{~cm}^{-1}$ in ARS-adsorbed GO/ PAMAM at $\mathrm{pH}=0$, Figure $3(\mathrm{c}), 1149.4 \mathrm{~cm}^{-1}$ in ARS-adsorbed GO/PAMAM at $\mathrm{pH}=2$, Figure $3(\mathrm{~d})$ and 1141.6 $\mathrm{cm}^{-1}$ in ARS-adsorbed GO/PAMAM at $\mathrm{pH}=5$, Figure 3(e). This red-shifting validated interaction of this group with sulfonate group of $A R S^{-}$molecules. Also, the peak of amide group in GO/PAMAM at $1637 \mathrm{~cm}^{-1}$, Figure 3(a), was observed at 1637, 1637 and $1638 \mathrm{~cm}^{-1}$ in spectra of ARS-adsorbed GO/PAMAM at pHs of 0,2 and 5, Figures 3(c)-3(e), respectively and did not have wavelength shift. Therefore, from FTIR spectra, it was concluded that in acidic solutions $-\mathrm{NH}_{3}^{+}$and phenolic $-\mathrm{OH}$ groups of GO/PAMAM interacted with sulfonate group of $A R S^{-}$molecules. In this work, the functional groups of GO/PAMAM that interacted with ARS molecules are called its adsorption sites.

At first, the adsorption of ARS molecules in alkaline media was studied. From its $p K_{a 1}$ and $p K_{a 2}$ value, ARS de- a)<smiles>O=C1c2ccccc2C(=O)c2c1cc([S+](=O)[O-])c(O)c2O</smiles>

$\mathrm{ARS}^{-}$

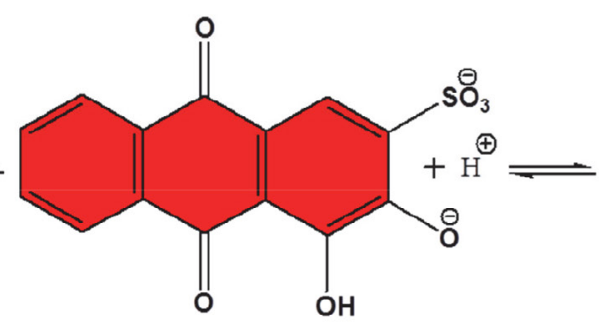

$\mathrm{ARS}^{2-}$

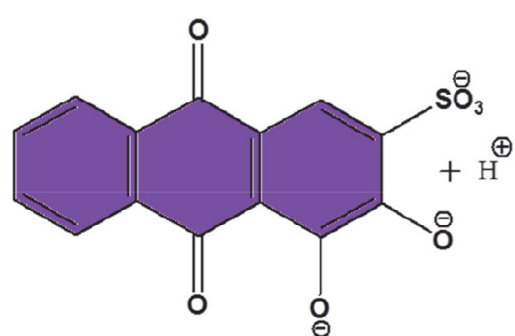

$\mathrm{ARS}^{3-}$ b)

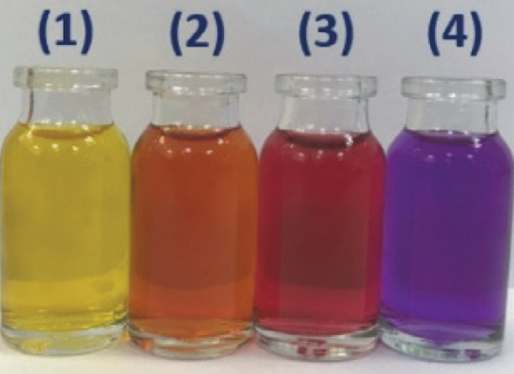

Figure 6. (a) Equilibrium relations among different types of ARS molecules at various $\mathrm{pHs}$ and (b) various forms of ARS molecules at (1) $\mathrm{pH}=3$, (2) $\mathrm{pH}=5$, (3) $\mathrm{pH}=11$ and $\mathrm{pH}=13$. protonated into $A R S^{2-}$ molecules at $\mathrm{pH}=10$ and $A R S^{3-}$ molecules at pHs of 13 and 14, respectively. Adsorption isotherms at $\mathrm{pHs}$ of 10,13 and 14 consisted of two curves, Figures $7(\mathrm{a})$ and $7(\mathrm{~b})$. At $\mathrm{pH}=10, A R S^{2-}$ molecules and at $\mathrm{pH}=13, A R S^{3-}$ molecules interacted first with $-\mathrm{NH}^{+}{ }_{3}$ (in the first curve) and subsequently with $-\mathrm{NH}_{2}$ (in the second curve) sites of GO/PAMAM surface, respectively.

The observed decrease in $q_{\text {sss }}$ value in isotherm at $\mathrm{pH}=10$ compared to isotherm at $\mathrm{pH}=13$ was resulted from a decrease in the number of $-\mathrm{NH}^{+}{ }_{3}$ groups of adsorbent surface. An increase in the negative charge of ARS molecule, as solution $\mathrm{Ph}$ was increased from 10 to 13, resulted in an increase in the electrostatic repulsion between adsorption sites and ARS molecules which in turn resulted in a decrease in $K$ values of regions I, IIA and IIB from $\mathrm{pH}$ 

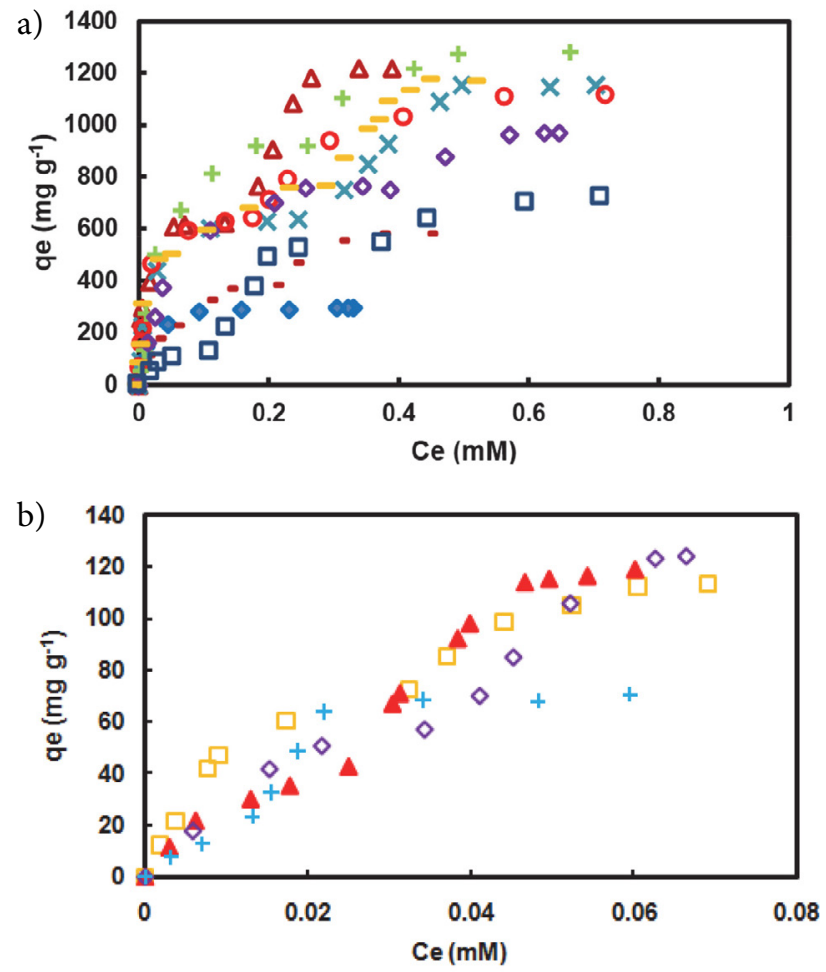

Figure 7. Adsorption isotherms of ARS on GO/PAMAM at 100 $\mathrm{rpm}$ and (a) at $\bullet \mathrm{pH}=0,-\mathrm{pH}=0.3, \Delta \mathrm{pH}=1,-\mathrm{pH}=3$ and $\square \mathrm{pH}$ $=5$ at $318 \mathrm{~K}$ and $\mathrm{pH}=2$ at $\times 308, \mathrm{O} 318$ and $+328 \mathrm{~K}$ and $(\mathrm{b})$ at $\square$ $\mathrm{pH}=10, \boldsymbol{\Delta} \mathrm{pH}=13$ and $+\mathrm{pH}=14$ at $318 \mathrm{~K}$.

$=10$ to $\mathrm{pH}=13$, Table 2 .

At $\mathrm{pH}=14, A R S^{3-}$ molecules interacted with $-\mathrm{NH}_{2}$ sites. As seen from Table 2, adsorption binding constants of $A R S^{3-}$ molecules with $-\mathrm{NH}_{2}$ site at $\mathrm{pH}=14$ (region IIA) and $-\mathrm{NH}_{2}$ site at $\mathrm{pH}=13$ (region IIB) and the adsorption binding constant of $A R S^{2-}$ molecules with $-\mathrm{NH}_{2}$ site at $\mathrm{pH}$ $=10$ (region IIB) were comparable.

In alkaline solutions, due to the low adsorption of ARS molecules on the surface, no CRAC was observed in adsorption isotherms, Table 3.

Then, the adsorption of ARS molecules on the surface of GO/PAMAM was studied in a water solution. The $\mathrm{pH}$ of these series of ARS solutions was about 5. Both $A R S^{-}$and $A R S^{2-}$ species appeared in the aqueous solution, in which $A R S^{-}$was the predominate species. Under the $\mathrm{pH}$ environment, $P h$ and $-\mathrm{NH}^{+}{ }_{3}$ sites were present on the surface of adsorbent. Given that the polarity of $\mathrm{O}-\mathrm{H}$ bond is stronger than that of $\mathrm{N}-\mathrm{H}$ bond, in region I and IIA (the first curve), $A R S^{-}$molecules interact with $P h$ sites first and then with $-\mathrm{NH}^{+}{ }_{3}$ sites, respectively.

Before adding adsorbent to the solutions, the color of solutions was brown (a mixture of $A R S^{-}$and $A R S^{2-}$ molecules). At the end of region IIB (the second curve) and $\mathrm{CRAC}_{\mathrm{C2}-\mathrm{C3}}$ (the CRAC between regions IIB and IIC), the color of the solutions in region IIC (the third curve) became red that confirmed $A R S^{-}$molecules adsorbed on the surface of GO/PAMAM in regions I, IIA and IIB. With an increase in the initial concentration of solution the color became paler, Figures 8(a) and 8(b). By considering the changes in the color of ARS solutions, it was speculated that in regions I, IIA and IIB, $A R S^{-}$molecules (in brown color) adsorbed on $\mathrm{Ph}$ and then on $-\mathrm{NH}^{+}{ }_{3}$ sites respectively. This adsorption step is followed by $A R S^{2-}$ molecules (in red color) adsorbed on the remaining $-\mathrm{NH}^{+}$sites in region IIC. As seen from experimental data in Table 2, the

Table 2. Adsorption equilibrium constants obtained from the Henry and Temkin equations based on the ARIAN model and experimental $s s_{A}$, $q_{s s A}, s s c_{B}, q_{s s B}, c_{\max }$ and $q_{e, \max }$ values for adsorption of ARS on GO/PAMAM in water, alkaline and acidic solutions in regions I, IIA, IIB and IIC at $100 \mathrm{rpm}$ and $308-328 \mathrm{~K}$.

\begin{tabular}{|c|c|c|c|c|c|c|c|c|c|c|c|c|c|}
\hline \multirow[t]{3}{*}{ Solvent } & \multirow{3}{*}{$\begin{array}{c}T \\
(\mathrm{~K})\end{array}$} & \multicolumn{3}{|c|}{ Henry (region I) } & \multicolumn{3}{|c|}{ Temkin (region IIB) } & \multicolumn{3}{|c|}{ Temkin (region IIC) } & & & \\
\hline & & \multirow{2}{*}{\multicolumn{3}{|c|}{${A R S^{-} \text {on } P h \text { site }}^{\mathcal{q}_{s s c B}}$}} & & $s s c_{C}$ & $q_{s s c C}$ & \multirow{2}{*}{\multicolumn{3}{|c|}{ 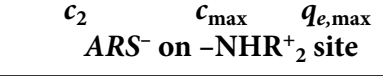 }} & & & \\
\hline & & & & & \multicolumn{3}{|c|}{$\mathrm{ARS}^{-}$on $-\mathrm{NH}_{3}^{+}$site } & & & & & & \\
\hline $\mathrm{pH}=0$ & 318 & $3.32 \times 10^{7}$ & $2.25 \times 10^{-3}$ & 72.7 & $1.55 \times 10^{6}$ & 0.16 & 291.1 & - & - & - & - & - & - \\
\hline $\mathrm{pH}=0.3$ & 318 & $8.41 \times 10^{6}$ & $1.29 \times 10^{-2}$ & 107.9 & $1.96 \times 10^{5}$ & 0.21 & 380.4 & $1.58 \times 10^{4}$ & 0.37 & 575.6 & - & - & - \\
\hline $\mathrm{pH}=1$ & 318 & $7.19 \times 10^{7}$ & $3.56 \times 10^{-3}$ & 252.6 & $2.26 \times 10^{5}$ & 0.18 & 759.6 & $1.08 \times 10^{4}$ & 0.27 & 1182.6 & - & - & - \\
\hline \multirow[t]{3}{*}{$\mathrm{pH}=2$} & 308 & $4.95 \times 10^{7}$ & $4.45 \times 10^{-3}$ & 222.7 & $1.73 \times 10^{6}$ & 0.25 & 636.7 & $7.39 \times 10^{3}$ & 0.38 & 929.4 & - & - & - \\
\hline & 318 & $3.22 \times 10^{7}$ & $4.81 \times 10^{-3}$ & 154.7 & $6.19 \times 10^{5}$ & 0.18 & 633.2 & $1.60 \times 10^{4}$ & 0.41 & 1027.6 & - & - & - \\
\hline & 328 & $1.09 \times 10^{7}$ & $7.03 \times 10^{-3}$ & 133.7 & $2.85 \times 10^{5}$ & 0.18 & 919.3 & $2.36 \times 10^{4}$ & 0.49 & 1275.2 & - & - & - \\
\hline $\mathrm{pH}=3$ & 318 & $3.09 \times 10^{7}$ & $4.96 \times 10^{-3}$ & 154.2 & $8.43 \times 10^{5}$ & 0.23 & 754.2 & $9.26 \times 10^{3}$ & 0.39 & 1091.5 & - & - & - \\
\hline \multirow{2}{*}{\multicolumn{2}{|c|}{ Adsorption in }} & \multicolumn{3}{|c|}{ Henry $(\text { region I })^{A}$} & \multicolumn{3}{|c|}{ Temkin (region IIA) ${ }^{\mathbf{A}}$} & \multicolumn{3}{|c|}{ Temkin (region IIB) $)^{B}$} & \multicolumn{3}{|c|}{ Temkin (region IIC) ${ }^{\mathrm{C}}$} \\
\hline & & $K$ & $s s c_{A}$ & $q_{s s c A}$ & $c_{2}$ & $s s c_{B}$ & $q_{s s c B}$ & $c_{2}$ & $\boldsymbol{s s c}_{C}$ & $q_{s s c C}$ & $c_{2}$ & $c_{\max }$ & $q_{e, \max }$ \\
\hline $\mathrm{pH}=5^{\star}$ & 318 & $2.47 \times 10^{6}$ & $3.15 \times 10^{-2}$ & 79.1 & $2.39 \times 10^{5}$ & 0.16 & 291.1 & $1.15 \times 10^{4}$ & 0.38 & 544.3 & $1.49 \times 10^{4}$ & 0.45 & 637.0 \\
\hline $\mathrm{pH}=10^{* \mathrm{D}}$ & 318 & $5.70 \times 10^{6}$ & $3.74 \times 10^{-3}$ & 21.4 & $7.29 \times 10^{5}$ & 0.03 & 72.6 & $9.98 \times 10^{4}$ & $6.5 \times 10^{-2}$ & 112.5 & - & - & - \\
\hline $\mathrm{pH}=13^{\star \mathrm{D}}$ & 318 & $3.50 \times 10^{6}$ & $6.19 \times 10^{-3}$ & 21.7 & $6.66 \times 10^{5}$ & 0.02 & 42.8 & $5.86 \times 10^{4}$ & $4.7 \times 10^{-2}$ & 114.0 & - & - & - \\
\hline $\mathrm{pH}=14^{\star \mathrm{E}}$ & 318 & $1.71 \times 10^{6}$ & $1.32 \times 10^{-2}$ & 23.3 & $9.94 \times 10^{4}$ & 0.03 & 63.7 & - & - & - & - & - & - \\
\hline
\end{tabular}

Units of $K$ and $c_{2}$ are in $\mathrm{mg} \mathrm{g}^{-1} \mathrm{M}^{-1}$ and $\mathrm{M}^{-1}$. Units of $s s c_{A}, s s c_{B}, s s c_{C}$ and $c_{\max }$ are in mg. Units of $q_{s s c A}, q_{s s c B}, q_{s s c C}$ and $q_{e, \max }$ are in $\mathrm{mg} \mathrm{g}^{-1}$. ${ }^{*}$ Adsorption sites and ARS types at these $\mathrm{pHs}$ are discussed in text. ${ }^{\mathrm{A}}$ Regions I and IIA are in the first curve (Ph site). ${ }^{\mathrm{B}}$ Region IIB is in the second curve (-NH ${ }_{3}^{+}$site).

${ }^{\mathrm{C}}$ Region IIC is in the third curve $\left(-\mathrm{NHR}^{+}{ }_{2}\right.$ site). ${ }^{\mathrm{D}} \mathrm{At} \mathrm{pHs}$ of 10 and $13, q_{s s c C}=q_{e, \max }$ and $s s c_{c}=c_{\max } . \mathrm{At} \mathrm{pH}=14, q_{s s c B}=q_{e, \max }$ and $s s c_{B}=c_{\max }$. 
Table 3. CRACs for the adsorption of ARS on GO/PAMAM in water, alkaline and acidic solutions at $100 \mathrm{rpm}$ and 308-328 K.

\begin{tabular}{|c|c|c|c|c|c|c|c|}
\hline Solvent & $\begin{array}{c}T \\
(\mathbf{K})\end{array}$ & $\begin{array}{c}\operatorname{ssc}_{B} \\
(\mathrm{mM})\end{array}$ & $\begin{array}{c}\mathrm{CRAC}_{C 1-C 2} \\
(\mathrm{mM})\end{array}$ & - & $\begin{array}{c}s s c_{C} \\
(\mathbf{m M})\end{array}$ & $\begin{array}{l}c_{\max } \\
(\mathbf{m M})\end{array}$ & $\begin{array}{c}q_{e, \max } \\
\left(\mathrm{mg} \mathrm{g}^{-1}\right)\end{array}$ \\
\hline $\mathrm{pH}=0$ & 318 & $2.25 \times 10^{-3}$ & - & - & 0.16 & 0.16 & 291.1 \\
\hline $\mathrm{pH}=0.3$ & 318 & $1.29 \times 10^{-2}$ & $0.14-0.21$ & - & 0.21 & 0.37 & 575.6 \\
\hline $\mathrm{pH}=1$ & 318 & $3.56 \times 10^{-3}$ & $0.07-0.18$ & - & 0.18 & 0.27 & 1182.6 \\
\hline \multirow[t]{3}{*}{$\mathrm{pH}=2$} & 308 & $4.45 \times 10^{-3}$ & $0.20-0.25$ & - & 0.25 & 0.38 & 929.4 \\
\hline & 318 & $4.81 \times 10^{-3}$ & $0.14-0.18$ & - & 0.18 & 0.41 & 1027.6 \\
\hline & 328 & $7.03 \times 10^{-3}$ & $0.18-0.26$ & - & 0.18 & 0.49 & 1275.2 \\
\hline $\mathrm{pH}=3$ & 318 & $4.96 \times 10^{-3}$ & $0.23-0.29$ & - & 0.23 & 0.39 & 1091.5 \\
\hline Solvent & $T$ & $s s c_{A}$ & $s s c_{B}$ & $\mathrm{CRAC}_{C 2-\mathrm{C} 3}$ & $s s c_{C}$ & $c_{\max }$ & $q_{e, \max }$ \\
\hline $\mathrm{pH}=5$ & 318 & $3.15 \times 10^{-2}$ & 0.11 & $0.25-0.38$ & 0.38 & 0.45 & 637.0 \\
\hline Solvent & $T$ & $s s c_{A}$ & $\mathrm{CRAC}_{C 1-C 2}$ & $s s c_{B}$ & $\operatorname{ssc}_{C}$ & $c_{\max }$ & $q_{e, \max }$ \\
\hline $\mathrm{pH}=10$ & 318 & $3.74 \times 10^{-3}$ & - & $3.2 \times 10^{-2}$ & - & $6.5 \times 10^{-2}$ & 112.5 \\
\hline $\mathrm{pH}=13$ & 318 & $6.19 \times 10^{-3}$ & - & $2.5 \times 10^{-2}$ & - & $4.7 \times 10^{-2}$ & 114.0 \\
\hline $\mathrm{pH}=14$ & 318 & $1.32 \times 10^{-2}$ & - & - & - & $3.4 \times 10^{-2}$ & 63.7 \\
\hline
\end{tabular}

$s s c_{A}, s s c_{B}, s s c_{C}$ are the starting concentrations of regions IIA, IIB and IIC respectively and their units are in mM. CRAC $\mathrm{Cl}_{-C 2}$ and $\mathrm{CRAC}_{\mathrm{C} 2-\mathrm{C} 3}$ are the concentration range of leveling off the adsorption isotherm between the first and second and the second and third curves, respectively and their unit is in $\mathrm{mM}$.

maximum adsorption capacity of regions I and IIA is $q_{s s c B}$ $=291,1 \mathrm{mg} \mathrm{g}^{-1}$, which was much bigger than those of reported for $\mathrm{ARS}^{43}$ and orange $\mathrm{IV}^{44}$ which interacted with
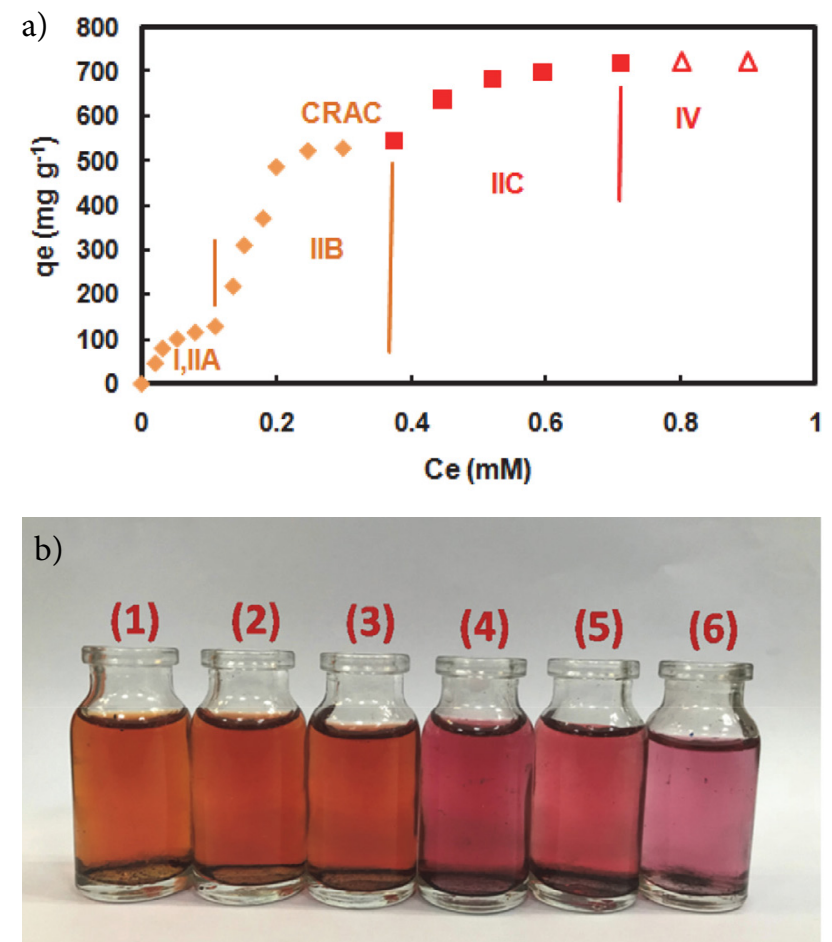

Figure 8. (a) Adsorption isotherm of ARS on GO/PAMAM at $\mathrm{pH}=$ 5 which showed adsorption of $A R S^{-}$molecules on $P h$ (region I) and $-\mathrm{NH}_{3}^{+}$(region IIA) sites and $A R S^{2-}$ molecules on $-\mathrm{NH}_{3}^{+}$(region IIB) sites, respectively. (b) Solutions in bottles 1-3 belonged to regions I, IIA and the second CRAC. Solutions in bottles $4-6$ belonged to region IIB and initial ARS concentrations increased from bottles 1 to 6 .
GO. However, our $q_{s s c B}$ was smaller than that of the second and third curves, $q_{\text {max }, e}-q_{s s c B}=345,9 \mathrm{mg} \mathrm{g}^{-1}$, Table 2 . Then, it was concluded that in region IIC, $A R S^{2-}$ molecules interacted with some remaining $-\mathrm{NH}_{3}^{+}$sites.

As seen from Table 2, at $\mathrm{pH}=5$ and $318 \mathrm{~K}, A R S^{-}$in region IIB and then $A R S^{2-}$ in region IIC interacted with $\mathrm{NH}^{+}{ }_{3}$ sites. The $K$ value of the former interaction was higher than the latter one. Given the negative charge of $A R S^{2-}$ was higher than that of $A R S^{-}$, the $K$ values observed in region IIC were less than those in region II, Figures 8 and 9. The observation of $\mathrm{K}$ values was attributed from two aspects: (1) the steric hindrance caused by the adsorbed ARS molecules; (2) increasing repulsion interaction between ARS molecules and negatively charged adsorbent surface.

Alizarin (AZ) was used to determine the functional group responsible for interacting ARS with GO/PAMAM in alkaline media. AZ molecule shares the same structure as ARS except for the missing sulfonate group, Figure 10. The $\mathrm{pK}_{\mathrm{a}}$ of $\mathrm{AZ}$ is 6.77 and both hydroxyl groups of $\mathrm{AZ}$ are ionized under an alkaline environment. ${ }^{45}$ Experiments showed that AZ adsorption capacity of GO/PAMAM at $\mathrm{pH}=12$ was $21.6 \mathrm{mg} \mathrm{g}^{-1}$ that was much less than the ARS adsorption capacity of $113.4 \mathrm{mg} \mathrm{g}^{-1}$ under similar conditions. This test verified that the sulfonate group of $A R S^{2-}$ and $A R S^{3-}$ molecules but not their $-O^{-}$groups interacted with GO/PAMAM in alkaline media.

Finally, the adsorption of ARS on GO/PAMAM was studied in acidic solutions, $\mathrm{pH} \leq 3$. Visible spectroscopy technique showed that only $A R S^{-}$molecules appeared in this range of $\mathrm{pHs}$. As reported before, ${ }^{42}$ with the decrease in $\mathrm{pH}(\mathrm{pH}<4)$ all the tertiary amines were protonated. Due to the repulsion between primary and tertiary amines of PAMAM dendrimer, its structure was opened, yielding 


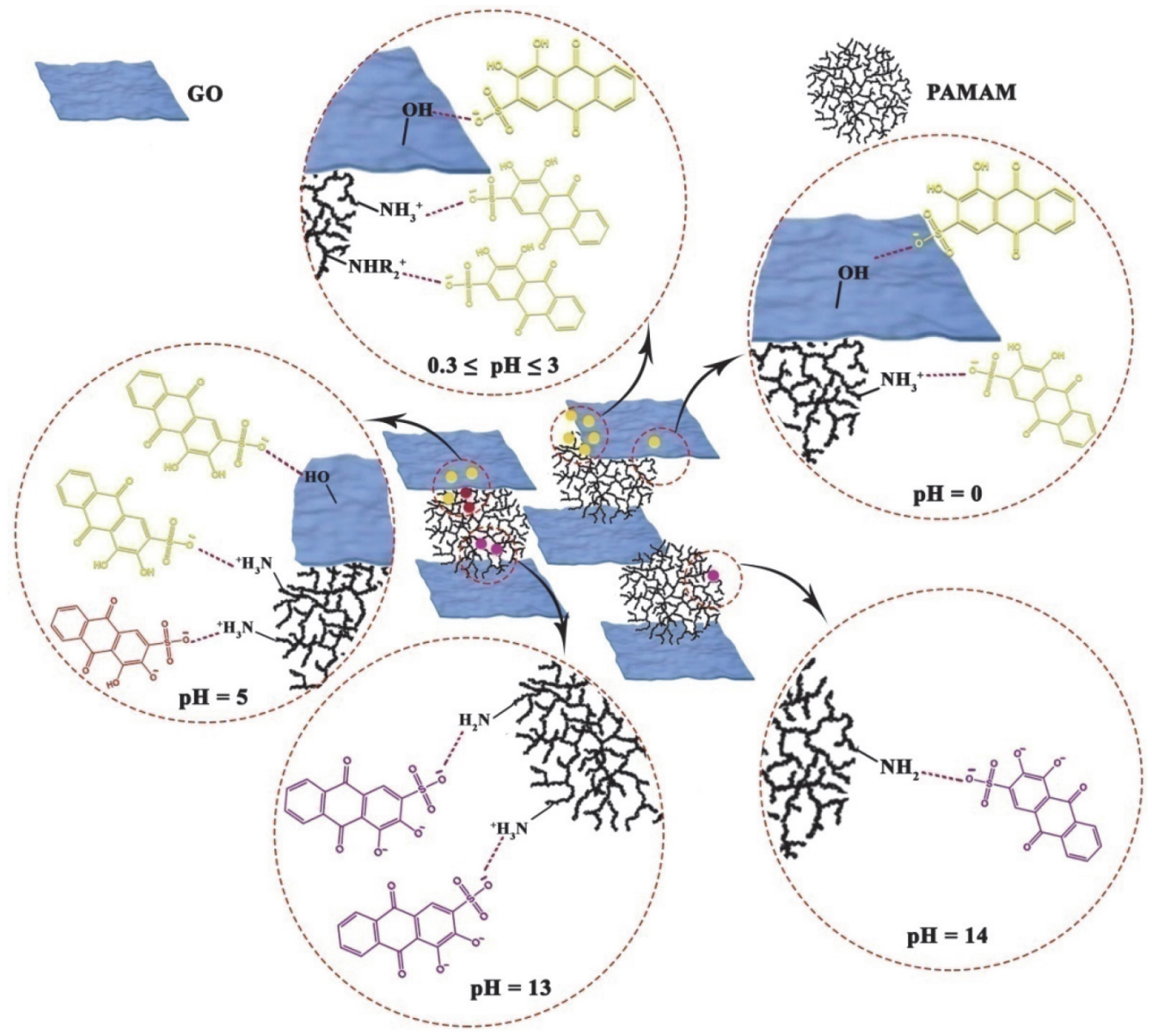

Figure 9. Adsorption sites of GO/PAMAM for different types of ARS molecules at different pHs.

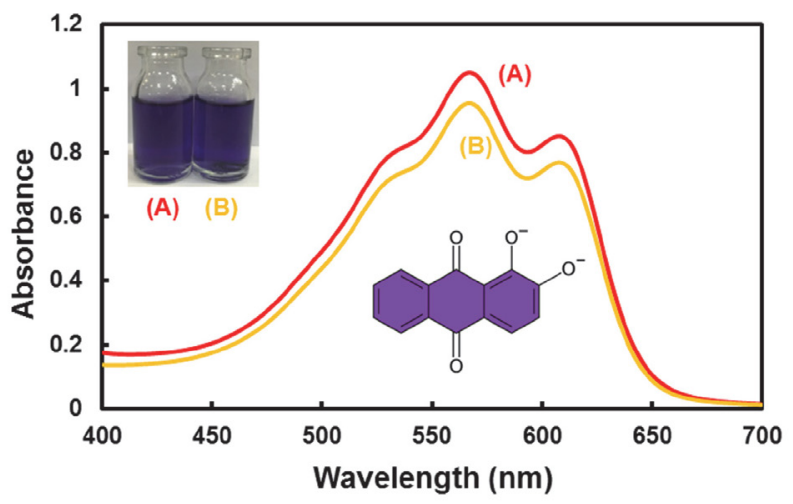

Figure 10. Absorption spectra of (A) $0.1 \mathrm{mM} \mathrm{AZ}$ and (B) $0.1 \mathrm{mM}$ $\mathrm{AZ}$ in the presence of $0.001 \mathrm{~g} \mathrm{GO} / \mathrm{PAMAM}$. The molecular structure of $\mathrm{AZ}$ at $\mathrm{pH}=12$ is shown in this figure.

an ideal interaction between the $P h$ groups of GO moiety of adsorbent and $A R S^{-}$molecules. Thus, the adsorption of ARS on the pristine GO/PAMAM obeyed only from the Henry equation (region I) without forming region IIA. Under these conditions more primary and tertiary amine groups exposed to $A R S^{-}$molecules. Due to binding three alkyl groups to $\mathrm{N}$ atom of tertiary amines, the polarity of $\mathrm{N}-\mathrm{H}$ bond of protonated tertiary amines form is less than that for $\mathrm{N}-\mathrm{H}$ bond of protonated primary amines $-\mathrm{NH}^{+}{ }_{3}$ and $\mathrm{O}-\mathrm{H}$ bond of $\mathrm{Ph}$ groups.

As shown in Tables 2, S1-S3 and Figure 7, the adsorption of $A R S^{-}$molecules at $\mathrm{pH} \leq 3$ occurred in three regions (I, IIB and IIC). However, the adsorption of $A R S^{-}$ molecules at $\mathrm{pH}=0$ happened in two regions (I and IIB) and their related adsorption isotherms were formed from two curves.

Thus, $A R S^{-}$molecules adsorbed on $\mathrm{Ph},-\mathrm{NH}^{+}{ }_{3}$ and $-\mathrm{NHR}_{2}^{+}$sites in region I and sections IIB and IIC, respectively. As shown in Tables 2, 3, S1-S3 and Figures 7(a) and $7(\mathrm{~b})$, the maximum experimental adsorption capacity $\left(q_{e,-}\right.$ max) of the adsorption of $A R S^{-}$molecules on GO/PAMAM at $\mathrm{pHs}$ of 1,2 and 3 were comparable. This implied that an increase in ionic strength of solutions at $\mathrm{pHs}$ from 3 to 1 did not affect the $q_{e, \max }$ of process. The adsorption binding constants $(K)$ in regions I and IIB at $318 \mathrm{~K}$ increased from pHs 1 to 3 . However, $K$ values in region IIC (on the $-\mathrm{NH}^{+}{ }_{3}$ sites) were approximately constant. Each of the adsorption isotherms at pHs of 1,2 and 3 consisted of two curves and a CRAC appeared between them, Table 3 . The presence of 
CRACs was due to the high adsorption capacity of adsorbent for $A R S^{-}$molecules in the concentration range of the first curve which resulted in steric hindrance of adsorbed $A R S^{-}$molecules on the adsorbent surface and electrostatic repulsion between adsorbent surface and $A R S^{-}$molecules.

At $\mathrm{pH}=2$, thermodynamic parameters of interaction of $\mathrm{ARS}^{-}$molecules with $\mathrm{Ph},-\mathrm{NH}^{+}{ }_{3}$ and $-\mathrm{NHR}^{+}$sites in regions I, IIB and IIC respectively, were calculated using the adsorption binding constants obtained from the Henry, Temkin and Temkin isotherms respectively, Table 2. $\Delta H$ and $\Delta S$ values were $63.2 \mathrm{~kJ} \mathrm{~mol}^{-1}$ and $-57.1 \mathrm{~J} \mathrm{~mol}^{-1} \mathrm{~K}^{-1}$ in region I, $75.8 \mathrm{~kJ} \mathrm{~mol}^{-1}$ and $-127.2 \mathrm{~J} \mathrm{~mol}^{-1} \mathrm{~K}^{-1}$ in region IIB and $48.9 \mathrm{~kJ} \mathrm{~mol}^{-1}$ and $237.8 \mathrm{~J} \mathrm{~mol}^{-1} \mathrm{~K}^{-1}$ in region IIC, respectively.

Afterwards, the Thermodynamic parameters of the adsorption were analyzed. Adsorption in the liquid phase, occurred through two kinds of interactions. One of them is the interaction of adsorbate molecules with surface of adsorbent and the other is due to replacing water molecules attached to the surface by adsorbate molecules.

The former interaction, by immobilization of adsorbate molecules, lowers the entropy of adsorption system. The latter one increases the disorder and thus the entropy of adsorption system which is result of the mobility of detached water molecules. At $\mathrm{pH}=2$, the negative $\Delta S$ values observed in adsorption of $A R S^{-}$molecules on the surface of GO/PAMAM in region I and sections IIB, showed electrostatic (ion-ion or ion-dipole) interaction occurred between $A R S^{-}$molecules with $P h$ and $-\mathrm{NH}^{+}{ }_{3}$ adsorption sites of GO/PAMAM. The negative $\Delta H$ values of these interactions indicated that the adsorption process in these two regions were exothermic.

On the other hand, the large positive $\Delta S$ value in region IIC showed after initial electrostatic interaction between $A R S^{-}$molecules and $-\mathrm{NHR}^{+}{ }_{2}$ adsorption sites of GO/PAMAM surface, a hydrophobic interaction happened between $A R S^{-}$molecules and hydrocarbon chains of $-\mathrm{NHR}_{2}^{+}$adsorption site that detached a large number of water molecules solvating $A R S^{-}$molecules and $\mathrm{GO} /$ PAMAM surface. The positive sign of $\Delta H$ value of this interaction was due to: (1) required energy to separate more number of water molecules from the GO/PAMAM surface and $A R S^{-}$molecules and (2) subsequent hydrophobic interactions between $A R S^{-}$molecules and GO/PAMAM surface. ${ }^{46,47}$

It was observed that adsorption capacities of these two curves of isotherms (specially the second curve) decreased from $\mathrm{pH}=1$ to $\mathrm{pH}=0$. Adsorption capacities of the second curve decreased about $50 \%$ from $\mathrm{pH}=1$ to $\mathrm{pH}$ $=0.3$ and further disappeared at $\mathrm{pH}=0$ which showed gradual decrease in the availability of the second adsorption site with an increase of $\mathrm{HCl}$ concentration.

This observation was further investigated using the following tests. The comparison of EDS spectra of ARSadsorbed GO/PAMAM modified by $1 \mathrm{M} \mathrm{HCl}$ for 10 hours and pristine GO/PAMAM showed that atomic percentages of nitrogen were comparable, which were $24.75 \%$ and $23.13 \%$ in the former and latter samples, respectively (without considering atomic percentage of its chlorine), Figures S3(a) and S3(b).

According to the measurements of nitrogen physisorption BET technique for pristine GO/PAMAM, ARS-adsorbed GO/PAMAM at $\mathrm{pH}=2$ and ARS-adsorbed $\mathrm{GO} / \mathrm{PAMAM}$ at $\mathrm{pH}=0, \mathrm{BET}$ surface area, maximum pore volume for slit pore geometry, adsorption average pore diameter (by BET) and pore volume were 9.59 $\mathrm{m}^{2} \mathrm{~g}^{-1}, 0.0044 \mathrm{~cm}^{3} \mathrm{~g}^{-1}, 18.9 \mathrm{~nm}$ and $0.045 \mathrm{~cm}^{3} \mathrm{~g}^{-1}$ for the first sample, $1.92 \mathrm{~m}^{2} \mathrm{~g}^{-1}, 0.001 \mathrm{~cm}^{3} \mathrm{~g}^{-1}, 14.2 \mathrm{~nm}$ and $0.0069 \mathrm{~cm}^{3} \mathrm{~g}^{-1}$ for the second sample and $1.35 \mathrm{~m}^{2} \mathrm{~g}^{-1}$, $0.0006 \mathrm{~cm}^{3} \mathrm{~g}^{-1}, 10.7 \mathrm{~nm}$ and $0.0036 \mathrm{~cm}^{3} \mathrm{~g}^{-1}$ for the third sample respectively, Figures $\mathrm{S} 1(\mathrm{a})-\mathrm{S} 1(\mathrm{c})$. The t-plot micropore area for ARS-adsorbed GO/PAMAM at $\mathrm{pH}=0$ was $0.0075 \mathrm{~m}^{2} \mathrm{~g}^{-1}$ and ARS-adsorbed GO/PAMAM at $\mathrm{pH}=2$ and pristine adsorbent were lack of micropores. These results showed that as GO/PAMAM at $\mathrm{pH}=0 \mathrm{ad}-$ sorbed less ARS molecules than GO/PAMAM at $\mathrm{pH}=2$, the BET surface area and slit pore volume of adsorbent at $\mathrm{pH}=0$ were less than those values at $\mathrm{pH}=2$ and part of adsorbent pores at $\mathrm{pH}=0$ changed to micropores.

The comparison of IR spectra of ARS-adsorbed GO/ PAMAM modified by $1 \mathrm{M} \mathrm{HCl}$ for 10 hours and pristine GO/PAMAM showed that those IR spectra were very similar, Figures 3(a) and 3(b). Also, the shift of broad peak around $2 \theta$ of $26.7^{\circ}$ in the XRD spectrum of GO/PAMAM to $26.4^{\circ}$ in the XRD spectrum of GO/PAMAM modified at $\mathrm{pH}=0$ showed a change in the structure of the latter one, Figures 2(a) and 2(b).

This evidence confirmed that the decrease in the adsorption capacities of the first and second curves of adsorption isotherms at pHs of 0.3 and 0 was due to masking the adsorption sites of GO/PAMAM. Indeed, a decrease in $\mathrm{pH}$ to less than 1 and an increase in ionic strength of solutions resulted in a shrinkage in PAMAM structure ${ }^{42}$ and possible interactions were between $-\mathrm{NH}^{+}{ }_{3}$ and polyamide groups of PAMAM dendrimer and between functional groups of PAMAM with a number of functional groups on the GO planes of adsorbent like its $\mathrm{C}=\mathrm{C}$ bonds and compressed its structure. This resulted in a decrease in the number of free $\mathrm{Ph}$ and $-\mathrm{NH}^{+}{ }_{3}$ groups and entrapment of $-\mathrm{NHR}^{+}$groups in internal structure of PAMAM and thus, resulted in a decrease in the availability of $\mathrm{Ph},-\mathrm{NH}^{+}{ }_{3}$ and $-\mathrm{NHR}^{+}{ }_{2}$ adsorption sites of GO/PAMAM for $A R S^{-}$molecules.

Finally, relative adsorption capacities of isotherms for regions I $\left(\frac{q_{\mathrm{scc} A}}{q_{e, \max }}\right), \operatorname{IIA}\left(\frac{q_{\mathrm{ssc} B}-q_{\mathrm{ssc} A}}{q_{e, \max }}\right), \operatorname{IIB}\left(\frac{q_{\mathrm{sscC}}-q_{\mathrm{scc} B}}{q_{e, \max }}\right)$ and IIC $\left(\frac{q_{c \text { max }}-q_{\text {ssc }}}{q_{e, \max }}\right)$ were given in Table S4. For example, because at $\mathrm{pH}=5$ the concentration of $A R S^{2-}$ molecules was less than $A R S^{-}$molecules, the adsorbent's relative adsorption capacity for $A R S^{2-}$ (region IIC) was 0.15 of $q_{e, \max }$ value. 


\section{2. Kinetics of Adsorption of ARS on GO/ PAMAM}

The adsorption mechanism of ARS on GO/PAMAM was studied by the KASRA model, and intraparticle diffusion and ISO equations using different ARS initial concentrations, temperatures, $\mathrm{pHs}$ and shaking rates. At $318 \mathrm{~K}$, using $0.25 \mathrm{mM}$ ARS at $\mathrm{pH}=0$ and using $0.07 \mathrm{mM}$ ARS at $\mathrm{pH}=2$, only one adsorption curve was observed in their kinetic diagrams without the presence of TRAK, implying that the adsorption of $A R S^{-}$molecules occurred on the $P h$ sites of adsorbent, Figures 11(a) and 11(b) and Table 4. gions (curves) were observed in all kinetic diagrams: $A R S^{-}$ molecules interacted with $\mathrm{Ph}$ sites in the first curve, followed by interaction with $-\mathrm{NH}^{+}{ }_{3}$ and $-\mathrm{NHR}_{2}^{+}$sites in the second one. It was observed that at $\mathrm{pH}=2$, ISO rate constants for the adsorption on the $P h$ sites (in the first region) increased with an increase of the shaking rate. Also, an increase in $\mathrm{pH}$ from 2 to 3 increased the ISO rate constants for the adsorption on $\mathrm{Ph},-\mathrm{NH}^{+}{ }_{3}$ and $-\mathrm{NHR}^{+}{ }_{2}$ sites.

At $\mathrm{pH}=2$, adsorption acceleration, initial velocity and $k_{d i f}$ for adsorption on $\mathrm{Ph},-\mathrm{NH}_{3}^{+}$and $-\mathrm{NHR}^{+}$sites increased with temperature, shaking rate and ARS initial concentration. The $k_{I 1}$ values at $0.7 \mathrm{mM}$ and $100 \mathrm{rpm}$, that
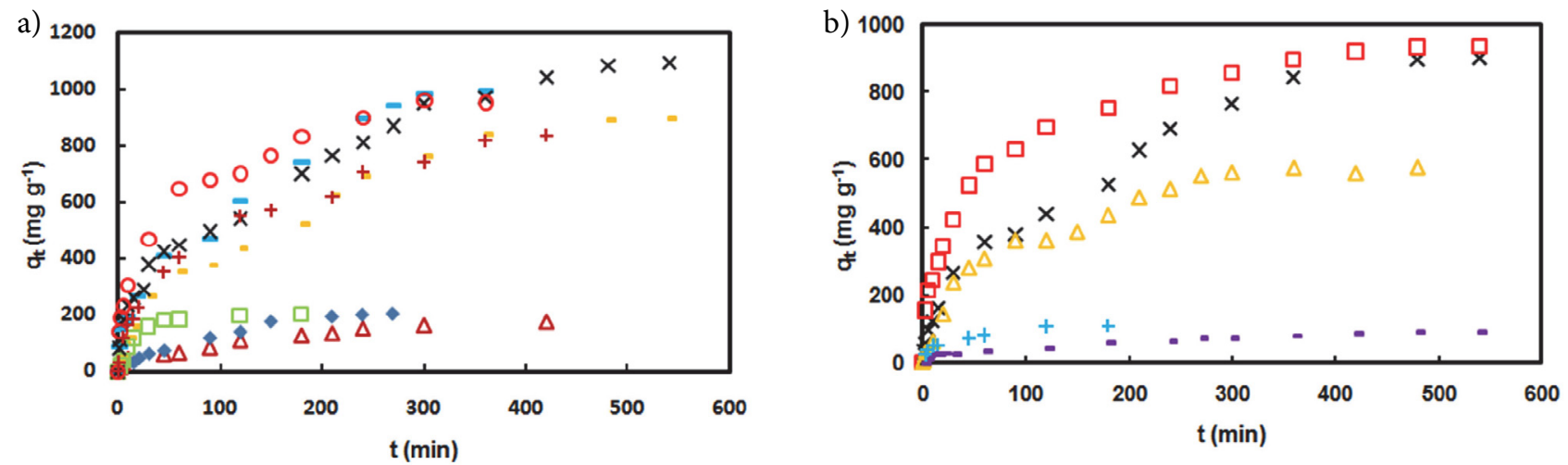

Figure 11. Kinetic curves of adsorption of ARS on GO/PAMAM (a) at $\bullet \mathrm{pH}=0$ and $0.25 \mathrm{mM}$ ARS and $\square \mathrm{pH}=2$ and $0.07 \mathrm{mM}$ ARS at $318 \mathrm{~K}$ and $100 \mathrm{rpm}$; at $\mathrm{pH}=2,0.7 \mathrm{mM}$ ARS and $-308, \times 318$ and $\mathrm{O} 328 \mathrm{~K}$ at $100 \mathrm{rpm}$; at $\Delta \mathrm{pH}=2,0.07 \mathrm{mM}$ ARS, $318 \mathrm{~K}$ and $100 \mathrm{rpm} ;$ at $\mathrm{pH}=2,0.7 \mathrm{mM}$ $\mathrm{ARS}$ and $318 \mathrm{~K}$ at -40 and $+70 \mathrm{rpm}$, respectively and (b) at $\times \mathrm{pH}=2,0.7 \mathrm{mM}$ ARS, $318 \mathrm{~K}$ and $40 \mathrm{rpm} ;$ at $\square \mathrm{pH}=3$ and $0.7 \mathrm{mM} \mathrm{ARS,} \Delta \mathrm{pH}=5$ and $1 \mathrm{mM}$ ARS, $-\mathrm{pH}=10$ and $0.07 \mathrm{mM}$ ARS and $+\mathrm{pH}=13$ and $0.07 \mathrm{mM}$ ARS at $318 \mathrm{~K}$ and $100 \mathrm{rpm}$.

Table 4. TRAKs for adsorption of ARS on GO/PAMAM in water, alkaline and acidic solutions at $100 \mathrm{rpm}$ and $308-328 \mathrm{~K}$.

\begin{tabular}{lccccccc}
\hline Solvent & $\begin{array}{c}\boldsymbol{T} \\
(\mathbf{K})\end{array}$ & $\begin{array}{c}{[\mathrm{ARS}]_{\mathbf{0}}} \\
(\mathbf{m M})\end{array}$ & $\mathbf{r p m}$ & $\begin{array}{c}\mathbf{T R A K}_{\mathbf{C I}-\mathrm{C2}} \\
(\mathbf{m i n})\end{array}$ & $\begin{array}{c}\boldsymbol{q}_{\text {TRAKC1-C2 }} \\
\left(\mathbf{m g ~ g}^{-\mathbf{1}}\right)\end{array}$ & $\begin{array}{c}\boldsymbol{t}_{\boldsymbol{e}} \\
(\mathbf{m i n})\end{array}$ & $\begin{array}{c}\boldsymbol{q}_{\boldsymbol{e}} \\
\left(\mathbf{m g ~ g}^{-\mathbf{1}}\right)\end{array}$ \\
\hline $\mathrm{pH}=0$ & 318 & 0.25 & 100 & - & - & 270 & 206.3 \\
$\mathrm{pH}=2$ & 318 & 0.07 & 100 & - & - & 180 & 202.3 \\
$(0.1 \mathrm{M} \mathrm{NaCl})$ & 318 & 0.07 & 100 & - & - & 420 & 174.0 \\
& 308 & 0.70 & 100 & - & - & 360 & 991.9 \\
& 318 & 0.70 & 100 & - & - & 420 & 965.9 \\
& 328 & 0.70 & 100 & - & - & 300 & 960.1 \\
& 318 & 0.70 & 70 & - & - & 360 & 815.4 \\
$\mathrm{pH}=3$ & 318 & 0.70 & 40 & - & - & 480 & 893.4 \\
$\mathrm{pH}=5$ & 318 & 0.70 & 100 & - & - & 480 & 931.5 \\
$\mathrm{pH}=10$ & 318 & 1.00 & 100 & $90-120$ & $362.2-362.5$ & 360 & 577.8 \\
$\mathrm{pH}=13$ & 318 & 0.07 & 100 & $10-30$ & $25.7-27.1$ & 480 & 90.4 \\
\hline
\end{tabular}

$T R A K_{C 1-C 2}$ is the TRAK between the first and second kinetic curves. $t_{e}$ is the time of starting plateau.

As seen from Tables 5 and 6 and S5-S7, adsorption acceleration, initial velocity, $k_{d i f}, k_{I 1}$ and $k_{I 2 a}$ decreased as $\mathrm{pH}$ decreased from 2 to 0 . This was resulted from the compression of the adsorbent structure at $\mathrm{pH}=0$, that blocked interior adsorption sites. Using $0.7 \mathrm{~mm}$ ARS at $\mathrm{pHs}$ of 2 and 3 at different shaking rates and temperatures two re- implied the interaction of $P h$ sites with $A R S^{-}$molecules increased with temperature. The activation energy of the adsorption in region I was $114.5 \mathrm{~kJ} \mathrm{~mol}^{-1}$. Therefore the adsorption of ARS on Ph sites was reaction-controlled. The adsorption in region $\mathrm{I}$ in region I only spanned about $6-8 \%$ of the whole adsorption duration but was accounted 
Table 5. Coefficients of the intraparticle diffusion equation for kinetics of ARS adsorption on GO/PAMAM at different temperatures and in various shaking rates and ARS initial concentrations.

\begin{tabular}{|c|c|c|c|c|c|c|c|c|c|c|c|c|c|}
\hline Solvent & $T$ & {$[\mathrm{ARS}]_{0}$} & rpm & KASRA & egion & 1st curve) & KASR & A region $2(1$ & st curve) & KASRA & regior & 2 (2nd & curve) \\
\hline & $(\mathrm{K})$ & $(\mathrm{mM})$ & & $k_{d i f}$ & $a_{1}$ & $\left(t_{2}, q_{2}\right)$ & $k_{\text {dif }}$ & $a_{2}$ & TRAK & $\left(t_{3}, q_{3}\right)$ & $k_{d i f}$ & $a_{3}$ & TRAK \\
\hline Correspondi & ng to & hermod & Iamic & AR & AN regi & & AR & IAN section & IB & ARIAI & N sec & ion IIC & \\
\hline At $p H \leq 3$ & sorpt & . & - on & & $P h$ site & & & $-\mathrm{NH}^{+}{ }_{3}$ site & & $-\mathrm{N}$ & $\mathrm{HR}_{2}^{+}$ & & \\
\hline $\mathrm{pH}=0$ & 318 & 0.25 & 100 & 11.2 & -0.048 & $(45,73.7)$ & 14.1 & $-4.0 \times 10^{-3}$ & - & - & - & - & - \\
\hline $\mathrm{pH}=2$ & 318 & 0.07 & 100 & 32.6 & -0.23 & $(45,181.8)$ & 3.2 & $-2.0 \times 10^{-3}$ & Adsorp & tion only o & n $P h s$ & ite - & - \\
\hline$(0.1 \mathrm{M} \mathrm{NaCl})$ & 318 & 0.07 & 100 & 19.2 & -0.47 & $(10,44.8)$ & 8.2 & $-1.6 \times 10^{-3}$ & Adsorp & tion only o & n Ph s & ite - & - \\
\hline & 308 & 0.70 & 100 & 97.1 & -10.40 & $(5,169.9)$ & 44.3 & -0.11 & - & $(90,469.2)$ & 56.2 & -0.012 & - \\
\hline & 318 & 0.70 & 100 & 82.5 & -14.28 & $(5,184.2)$ & 50.7 & -0.13 & - & $(60,449.2)$ & 45.4 & -0.006 & - \\
\hline & 328 & 0.70 & 100 & 105.7 & -16.94 & $(5,232.6)$ & 65.0 & -0.14 & - & $(90,681.0)$ & 37.9 & -0.004 & - \\
\hline & 318 & 0.70 & 70 & 66.3 & -4.00 & $(9,120.6)$ & 52.5 & -0.08 & - & $(60,402.8)$ & 35.3 & -0.002 & - \\
\hline & 318 & 0.70 & 40 & 43.8 & -2.40 & $(10,120.1)$ & 38.4 & -0.11 & - & $(90,376.7)$ & 44.9 & -0.004 & - \\
\hline $\mathrm{pH}=$ & 318 & 0.70 & 100 & 119.4 & -8.45 & $(5,2$ & 71.6 & -0.11 & - & $(60,585.1)$ & 24.9 & -0.002 & - \\
\hline $\mathrm{pH}=5^{\star}$ & 318 & 1.00 & 100 & 24.9 & -1.19 & $(10,61.8)$ & 75.0 & -0.106 & - & $(30,237.0)$ & 70.1 & -0.006 & $90-120$ \\
\hline & & & A re & n 1 (1 & urve) & & & & & KASRA & regi & 2 (2nd & urve) \\
\hline Correspondi & $n g t$ & ermoc & lamic & ARI & $\mathrm{N}$ regio & and secti & & & & ARI & $\mathrm{AN} \mathrm{s}$ & tion IIB & \\
\hline $\mathrm{pH}$ & 318 & 0.07 & 100 & 7.7 & -0.6 & - & - & - & $10-30$ & $(30,27.1)$ & & -4.0 & 4 \\
\hline $\mathrm{pH}=13^{*}$ & 318 & 0.07 & 100 & 19.8 & -0.95 & - & - & - & $10-15$ & $(15,53.7)$ & & $-4.0 \times$ & $-3-$ \\
\hline
\end{tabular}

Unit of $k_{d i f}$ is in $\mathrm{mg} \mathrm{g}^{-1} \mathrm{~min}^{-0.5}$. Units of $a_{1}, a_{2}$ and $a_{2}$ are in $\mathrm{mg} \mathrm{g}^{-1} \mathrm{~min}^{-2}$. Units of $t_{1}, t_{2}$ and $t_{3}$ are in min and those of $q_{1}, q_{2}$ and $q_{3}$ are in $\mathrm{mg} \mathrm{g}^{-1}$ and $t_{1}=q_{1}=0$. Boundary points coordinates of diffusion regions, $\left(t_{n}, q_{n}\right)$, are similar to those of the KASRA model, $\left(t_{0 n}, q_{0 n}\right)$ in Table S5. ${ }^{* A t}$ pH $=$ 5 , data from left to right belong to the first and second kinetic curves and the third kinetic curve (corresponding to the ARIAN section IIC) starts after second TRAK (90-120 min) and for that $k_{d i f}$ and $a_{4}$ are $36.3 \mathrm{mg} \mathrm{g}^{-1} \mathrm{~min}^{-0.5}$ and $-0.006 \mathrm{mg} \mathrm{g}^{-1} \mathrm{~min}^{-2}$, respectively. Adsorption sites and ARS types involved at $\mathrm{pHs}=5,10$ and 13 are discussed in text.

Table 6. Coefficients of region 1 and region 2 (parts $2 a$ and $2 b$ ) of the ISO equation for kinetics of ARS adsorption on different sites of GO/ PAMAM at $308-328 \mathrm{~K}$.

\begin{tabular}{|c|c|c|c|c|c|c|c|c|c|c|}
\hline Solvent & $\mathrm{T}$ & {$[\mathrm{ARS}]_{0}$} & & rpmKA & SRA region & s 1 and 2 (1st & urve) & & ASRA regio & 2 (2nd curve) \\
\hline & $(\mathrm{K})$ & $(\mathrm{mM})$ & $k_{I 1}$ & $k_{I 2 a}$ & $k_{I 2 b}$ & {$[\mathrm{ARS}]_{E}, t_{E}, q_{E}$} & $k_{I 2 a}$ & $k_{I 2 b}$ & & $\left.S]_{e}, t_{e}, q_{e}\right)$ \\
\hline Correspondir & ng to & thermo & lynam & & & & IAN region I and & I section IIA & & \\
\hline At $p H \leq 3$ ads & orpti & on of $A$ & $S^{-}$on & $P h$ site & $-\mathrm{NH}_{3}^{+}$site & & & $-\mathrm{NH}$ & $\mathrm{IR}_{2}^{+}$site & \\
\hline $\mathrm{pH}=0$ & 318 & 0.25 & 100 & $2.83 \times 10^{4}$ & $8.43 \times 10^{3}$ & $2.32 \times 10^{4}$ & - & - & - & $(0.196,270,206.3)$ \\
\hline $\mathrm{pH}=2$ & 318 & 0.07 & 100 & $3.91 \times 10^{5}$ & $1.87 \times 10^{5}$ & - & Adsorption onl & y on $P h$ site & - & $\begin{array}{c}\left(2.27 \times 10^{-2}\right. \\
180,202.2)\end{array}$ \\
\hline$(0.1 \mathrm{M} \mathrm{NaCl})$ & 318 & 0.70 & 100 & $6.46 \times 10^{4}$ & $1.44 \times 10^{4}$ & $9.33 \times 10^{4}$ & Adsorption onl & site & - & $\begin{array}{r}\left(2.42 \times 10^{-2}\right. \\
420,174)\end{array}$ \\
\hline & 308 & 0.70 & 100 & $1.69 \times 10^{4}$ & $1.83 \times 10^{4}$ & $3.89 \times 10^{4}$ & $(0.59,90,469.2)$ & $1.40 \times 10^{4}$ & $5.39 \times 10^{4}$ & $(0.49,360,991.9)$ \\
\hline & 318 & 0.70 & 100 & $8.57 \times 10^{4}$ & $1.70 \times 10^{4}$ & $7.11 \times 10^{4}$ & $(0.556,60,449.2)$ & $1.39 \times 10^{4}$ & $7.86 \times 10^{4}$ & $(0.418,420,965.9)$ \\
\hline & 328 & 0.70 & 100 & $2.57 \times 10^{5}$ & $2.88 \times 10^{4}$ & $7.84 \times 10^{4}$ & $(0.521,90,681.0)$ & $9.81 \times 10^{3}$ & $2.21 \times 10^{4}$ & $(0.391,300,960.1)$ \\
\hline & 318 & 0.70 & 70 & $6.55 \times 10^{4}$ & $1.66 \times 10^{4}$ & $2.99 \times 10^{4}$ & $(0.606,60,402.8)$ & $6.12 \times 10^{3}$ & $1.22 \times 10^{4}$ & $(0.533,360,815.4)$ \\
\hline & 318 & 0.70 & 40 & $3.15 \times 10^{4}$ & $3.19 \times 10^{4}$ & - & $(0.59,90,376.7)$ & $8.76 \times 10^{3}$ & $6.57 \times 10^{4}$ & $(0.204,480,893.4)$ \\
\hline $\mathrm{pH}=3$ & 318 & 0.70 & 100 & $1.27 \times 10^{5}$ & $6.23 \times 10^{3}$ & $1.35 \times 10^{4}$ & $(0.563,60,585.1)$ & $7.73 \times 10^{3}$ & $1.15 \times 10^{4}$ & $(0.482,480,931.5)$ \\
\hline $\mathrm{pH}=5^{\star}$ & 318 & 1.00 & 100 & $1.78 \times 10^{4}$ & $1.75 \times 10^{4}$ & $1.11 \times 10^{4}$ & $(0.85,90,362.2)$ & $7.81 \times 10^{3}$ & $1.77 \times 10^{4}$ & $(0.814,360,577.8)$ \\
\hline $\mathrm{pH}=10^{\star *}$ & 318 & 0.07 & 100 & $1.98 \times 10^{5}$ & - & - & $\begin{array}{c}\left(6.32 \times 10^{-2}\right. \\
10,25.7)\end{array}$ & $3.70 \times 10^{3}$ & $9.25 \times 10^{3}$ & $\begin{array}{r}\left(4.89 \times 10^{-2},\right. \\
480,90.4)\end{array}$ \\
\hline $\mathrm{pH}=13^{\star * *}$ & 318 & 0.07 & 100 & $2.35 \times 10^{5}$ & - & - & $\begin{array}{c}\left(5.79 \times 10^{-2}\right. \\
10,51.6)\end{array}$ & $3.59 \times 10^{4}$ & $1.14 \times 10^{5}$ & $\begin{array}{r}\left(5.21 \times 10^{-2},\right. \\
180,110.0)\end{array}$ \\
\hline
\end{tabular}

$[\mathrm{ARS}]_{E}, t_{E}$ and $q_{E}$ are ARS concentration, time and adsorption capacity at the end of adsorption on a type of adsorption site, respectively (corresponding to $[\mathrm{ARS}]_{e}, t_{e}$ and $q_{e}$ in the last curve). [ARS $]_{e}, t_{e}$ and $q_{e}$ are ARS concentration, time and adsorption capacity at the beginning of the plateau. Units of $k_{I 1}, k_{I 2 a}$ and $k_{I 2 b}$ are in $\mathrm{min}^{-1}$. [ARS $]_{E}$ and [ARS $]_{e}$ are in $\mathrm{mM}$. ${ }^{*} \mathrm{At} \mathrm{pH}=5$, data from left to right belong to the adsorption of $A R S^{-}$on $\mathrm{Ph}$ sites (1st kinetic curve), $A R S^{-}$on- $\mathrm{NH}^{+}{ }_{3}$ sites (2nd kinetic curve) and $A R S^{2-}$ on $-\mathrm{NH}^{+}{ }_{3}$ sites (3rd kinetic curve), respectively. ${ }^{* *} \mathrm{At} \mathrm{pH}=$ 10 , data from left to right belong to the adsorption of $A R S^{2-}$ on $-\mathrm{NH}_{3}^{+}$(1st kinetic curve) and $-\mathrm{NH}_{2}$ sites (2nd kinetic curve), respectively. ${ }^{* * *}$ At $\mathrm{pH}=13$, data from left to right belong to the adsorption of $A R S^{3-}$ on $-\mathrm{NH}_{3}^{+}$(1st kinetic curve) and $-\mathrm{NH}_{2}$ sites (2nd kinetic curve), respectively. 
for about $34-41 \%$ of the adsorption capacity of $\mathrm{GO} /$ PAMAM. The adsorption on $\mathrm{Ph}$ sites was much faster than those on the $-\mathrm{NH}^{+}{ }_{3}$ and $-\mathrm{NHR}_{2}^{+}$sites. On the other hand, under similar conditions, other rate constants obtained from the ISO equation changed randomly with temperature and thus the adsorption on the $-\mathrm{NH}^{+}{ }_{3}$ and $-\mathrm{NHR}^{+}{ }_{2}$ sites was diffusion-controlled.

At $\mathrm{pH}=2$ and $0.07 \mathrm{mM}$ ARS in $0.1 \mathrm{M} \mathrm{NaCl}$, adsorption acceleration, initial velocity and $k_{I 1}$ increased slightly compared to those values in a solution without $\mathrm{NaCl}$. This was due to more availability of $A R S^{-}$molecules to internal structure of PAMAM dendrimer with the ionic strength of solution. The slight increase in $k_{I 1}$ value with an increase in the ionic strength of solution confirmed that the adsorption interaction in region I occurs between $A R S^{-}$molecules and uncharged $P h$ groups of adsorbent.

At $\mathrm{pH}=5,318 \mathrm{~K}$ and $1 \mathrm{mM}$ ARS, adsorption acceleration, initial velocity, $k_{d i f}$ and $k_{I 1}$ of the adsorption on $\mathrm{Ph}$ and $-\mathrm{NH}_{3}^{+}$sites (first curve) were less than those at $\mathrm{pH}=$ $2,318 \mathrm{~K}$ and $0.7 \mathrm{mM}$ ARS. Because, at $\mathrm{pH}<4$, all the primary and tertiary amines were protonated and the repul-

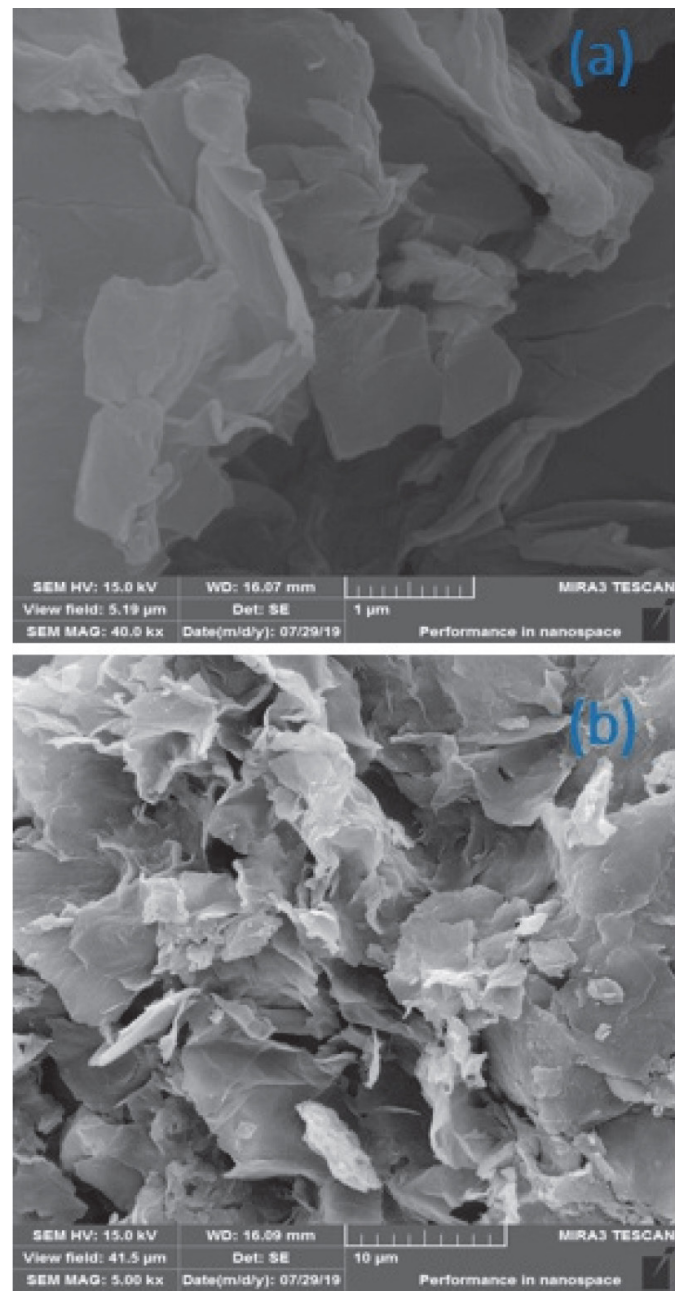

sion interaction between these amine groups of PAMAM dendrimer, its structure swelled ${ }^{42}$ to expose more adsorbent inner surface compared to that at $\mathrm{pH}=5$, Tables 5 and 6.

At $318 \mathrm{~K}$ and $0.07 \mathrm{mM}$ ARS, $A R S^{2-}$ molecules at $\mathrm{pH}$ $=10$ and $A R S^{3-}$ molecules at $\mathrm{pH}=13$ were adsorbed on $\mathrm{NH}_{3}^{+}$sites (first curve) and $-\mathrm{NH}_{2}$ sites (second curve) respectively. As the $\mathrm{pH}$ increased from 5 to 13 , the electron charge density on the adsorbent surface became higher, that increased the electrostatic repulsion between ARS molecules and adsorbent surface. The repulsive interaction yielded the appearance of TRAK in the kinetic diagrams Table 4.

\section{3 Recycling ARS-adsorbed GO/PAMAM}

For recycling ARS-adsorbed GO/PAMAM, several solvents were tested, such as, diethyl ether, methanol, ethanol, benzene, DMF, THF, DMSO, diethylenetriamine and alkaline and acidic aqueous solutions, none of them could extract ARS from the used adsorbent. However, we found
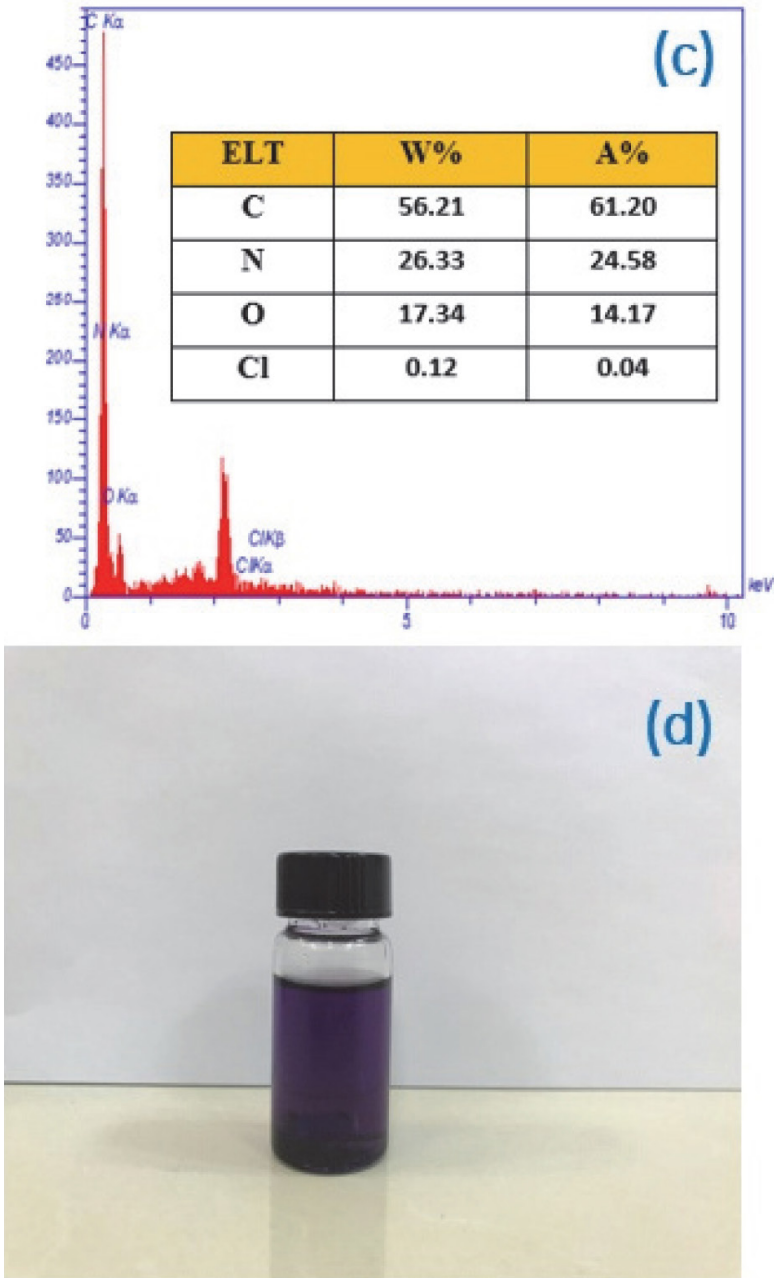

Figure 12. (a,b) SEM and (c) EDS images of the recycled GO/PAMAM and (d) extraction of ARS from the ARS-adsorbed GO/PAMAM by ethylenediamine. 
ethylenediamine extracted ARS from the ARS-adsorbed GO/PAMAM very fast and effectively. In a series of experiments, $0.006 \mathrm{~g}$ samples of pristine GO/PAMAM were added to $30 \mathrm{ml}$ of $10^{-3} \mathrm{M}$ ARS solution at $\mathrm{pH}=3$ at ambient temperature. The ARS-adsorbed adsorbents were separated from supernatant after $10 \mathrm{~h}$ followed by washing and drying. Then, about $45 \mathrm{ml}$ of ethylenediamine was added to the about $0.0025 \mathrm{~g}$ of the used adsorbent in three steps $(15 \mathrm{ml} /$ step). The adsorption capacity of pristine $\mathrm{GO} /$ PAMAM was fully regenerated. The EDS spectrum of the recycled adsorbent showed no trace of sulfur atom. The SEM images of the recycled adsorbent showed that its morphology was similar to that of the pristine GO/ PAMAM, Figures 12(a)-12(d). Finally, ARS was separated from the ethylenediamine solution (in purple) by the distillation process.

\section{4. Selective separation of some cationic dyes from ARS using GO/PAMAM}

The selective adsorption of ARS from these dyes can be used for making photochemical and electrochemical sensors. ${ }^{48-50}$ For studying selective separation capability of dyes from ARS by GO/PAMAM, methylene blue (MB), acridine orange $(\mathrm{AO})$, pyronin $\mathrm{Y}(\mathrm{PY})$, thionine $(\mathrm{Th})$ and janus green $\mathrm{B}$ (JG) cationic and methyl blue (MEB) anionic dyes were<smiles>CN(C)c1ccc2nc3ccc(N(C)C)cc3[s+]c2c1</smiles><smiles>CN(C)c1ccc2cc3ccc(=[N+](C)C)cc-3oc2c1</smiles><smiles>O=S(=O)([O-])c1ccc(Nc2ccc(C(=C3C=CC(=[NH+]c4ccc(S(=O)(=O)[O-])cc4)C=C3)c3ccc(Nc4ccc(S(=O)(=O)O)cc4)cc3)cc2)cc1</smiles>

mixed with ARS at $\mathrm{pH}=2$, Figures 13 and S5. Maximum wavelengths of ARS, MB, AO, PY, Th, JG and MEB were at $422,664,491,546,599,820$ and $599 \mathrm{~nm}$, respectively.

At this $\mathrm{pH}, \mathrm{GO} / \mathrm{PAMAM}$ had its maximum adsorption capacity for ARS. Using the adopted initial ARS concentration, ARS was fully removed from the solution. Comparison of the UV-Vis spectra of pure dyes solutions with those of ARS-dye mixtures (in the absence of adsorbent) showed that the strength of dye-ARS interaction followed the trend: JG (by formation of deposit) $>\mathrm{MB}, \mathrm{AO}$, PY $>$ Th $>$ MEB, peaks B and D of Figures 14(b) $-14(\mathrm{~g})$. The final concentrations of $\mathrm{Th}, \mathrm{MB}, \mathrm{AO}$ and $\mathrm{PY}$ in their mixtures with ARS were $95 \%, 56 \%, 45 \%$ and $56 \%$ of their initial concentrations, respectively. As shown in peaks $B$ and D of Figure 14(f), MEB and ARS anionic dyes do not interact together.

As shown in absorption peaks of $\mathrm{B}$ and $\mathrm{C}$ of Figures 14(b)-14(g), the final concentrations of Th, MB, AO, PY, JG and MEB after adsorption on the surface of $\mathrm{GO} /$ PAMAM were $67 \%, 84 \%, 83 \%, 93 \%, 70 \%$ and $22 \%$ of their initial concentrations, respectively.

But, as seen in peaks of B, E of Figures 14(b)-14(g), due to interaction of Th, MB, AO, PY and JG with adsorbed ARS on the surface of GO/PAMAM and adsorption of MEB on the surface of GO/PAMAM in the mixture of these dyes with ARS in the presence of GO/PAMAM, their final<smiles>Nc1ccc2nc3ccc(N)cc3[s+]c2c1</smiles><smiles>CN(C)c1ccc2cc3ccc(N(C)C)cc3nc2c1</smiles><smiles>CCN(CC)c1ccc2nc3ccc(/N=N/c4ccc(N(C)C)cc4)cc3[n+](-c3ccccc3)c2c1</smiles>

Figure 13. Molecular structure of (a) MB, (b) Th, (c) PY, (d) AO, (e) MEB and (f) JG. 

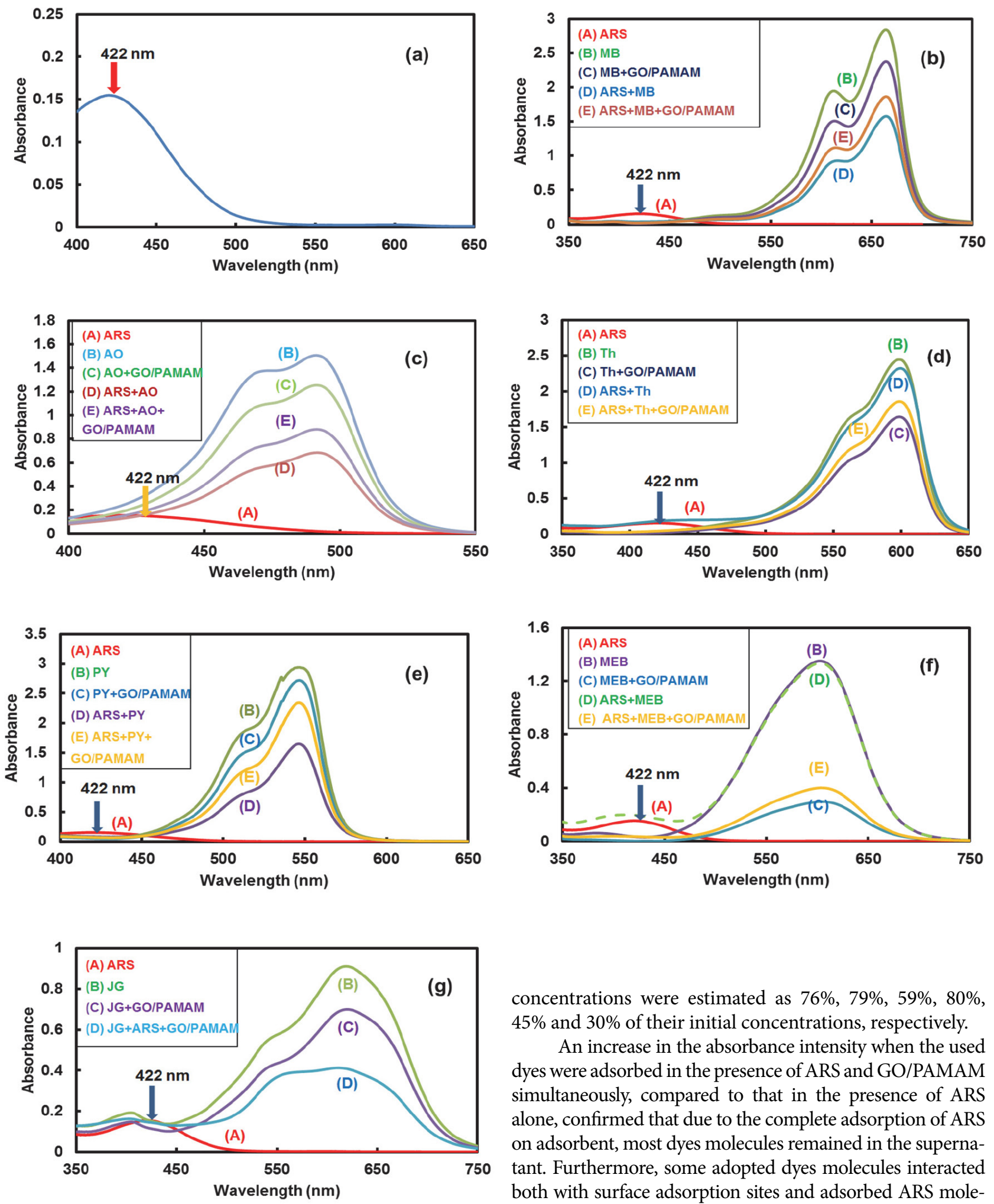

Figure 14. (a) Absorption peak of $\mathrm{ARS}$ at $\mathrm{pH}=2$. In all solutions, concentration of ARS was $5 \times 10^{-2} \mathrm{mM}$ and those of $\mathrm{MB}$ in (b), AO in (c), Th in (d), PY in (e) and MEB in (f) were $5 \times 10^{-2} \mathrm{mM}$ and concentration of JG in (g) was $2.5 \times 10^{-2} \mathrm{mM}$. Tests were carried out at $\mathrm{pH}=2$ and room temperature. In curves $(\mathrm{C})$ and $(\mathrm{E})$ of all figures the weight of used GO/PAMAM was $0.001 \mathrm{~g}$.

concentrations were estimated as $76 \%, 79 \%, 59 \%, 80 \%$, $45 \%$ and $30 \%$ of their initial concentrations, respectively.

An increase in the absorbance intensity when the used dyes were adsorbed in the presence of ARS and GO/PAMAM simultaneously, compared to that in the presence of ARS alone, confirmed that due to the complete adsorption of ARS on adsorbent, most dyes molecules remained in the supernatant. Furthermore, some adopted dyes molecules interacted both with surface adsorption sites and adsorbed ARS molecules, peaks of B, C of Figures 14(b)-14(g). It was observed that in the used initial concentrations of ARS and JG, the ARS-JG deposit formed in their mixture was completely dissolved in the presence of GO/PAMAM and the solution turned blue from colorless which was due to complete adsorption of ARS, Figure S5 and peak D of Figure 14(g). 


\section{Conclusions}

The adsorption of ARS on the surface of GO/ PAMAM was studied under different temperatures, $\mathrm{pHs}$, ARS initial concentrations, contact times and shaking rates. Adsorption isotherms were analyzed by the ARIAN model and its kinetic curves were investigated by the KASRA model and ISO and intraparticle diffusion equations. Analysis of adsorption isotherms and kinetic curves showed that phenolic $-\mathrm{OH}$ groups of GO moiety $(\mathrm{Ph})$ and $-\mathrm{NH}_{2},-\mathrm{NHR}_{2}^{+}$and $-\mathrm{NH}^{+}{ }_{3}$ groups of PAMAM dendrimer moiety of GO/PAMAM were adsorption sites of the adsorbent. Depending on the solution $\mathrm{pH}$, due to deprotonation, ARS formed three different species as $A R S^{-}, A R S^{2-}$ and $A R S^{3-}$. At acidic $\mathrm{pHs}, A R S^{-}$molecules interacted with $\mathrm{Ph},-\mathrm{NH}^{+}{ }_{3}$ and $-\mathrm{NHR}_{2}^{+}$in sequence. The adsorption on the $\mathrm{Ph}$ and $-\mathrm{NH}_{3}^{+}$sites were exothermic and the adsorption on the $-\mathrm{NHR}_{2}^{+}$sites was endothermic, respectively.

At pHs of 1,2 and $3, q_{e, \max }$ of the adsorbent for $A R S^{-}$ attained to maximum value and were similar together. At $\mathrm{pH}=2$ and $328 \mathrm{~K}, q_{e, \max }$ of GO/PAMAM (as a superadsorbent) for the adsorption of $A R S^{-}$was $1275.6 \mathrm{mg} \mathrm{g}^{-1}$. This was attributed to the open GO/PAMAM structure after the protonation of all primary and tertiary amine groups of PAMAM dendrimer. Due to the repulsion interaction between these groups, GO/PAMAM structure became very open and resulted in an increase in adsorption capacity of $\mathrm{GO} / \mathrm{PAMA}$ for ARS. At $\mathrm{pH}=2$, binding constant values of $A R S^{-}$molecules to $P h$ sites were higher than those of $\mathrm{NH}_{3}^{+}$and $-\mathrm{NHR}^{+}$sites of adsorbent. The interaction of $A R S^{-}$molecules with $P h$ sites was faster than that of $\mathrm{NH}_{3}^{+}$and $-\mathrm{NHR}^{+}$sites. The adsorption of $\mathrm{ARS}^{-}$on $\mathrm{Ph}$ sites was reaction-controlled. The activation energy obtained from its ISO rate constant was $114.5 \mathrm{~kJ} \mathrm{~mol}^{-1}$. However, the adsorption of $A R S^{-}$on the $-\mathrm{NH}^{+}{ }_{3}$ and $-\mathrm{NHR}^{+}{ }_{2}$ sites was diffusion-controlled.

The decrease in the $\mathrm{pH}$ of solutions from 1 to 0 resulted in a decrease in $q_{e, \max }$, which could be owe to fewer available $\mathrm{Ph},-\mathrm{NH}_{3}^{+}$and $-\mathrm{NHR}^{+}{ }_{2}$ groups of GO/PAMAM for ARS molecules that was caused by a shrinkage in GO/ PAMAM structure and masking some of functional groups of GO/PAMAM. Also, this resulted in a decrease in ISO rate constants with a decrease in $\mathrm{pH}$ from 2 to 0 . At $\mathrm{pH}=$ 5, $A R S^{-}$interacted first with $\mathrm{Ph}$ sites and then with $-\mathrm{NH}^{+}{ }_{3}$ sites. In continuation, $A R S^{2-}$ interacted with $-\mathrm{NH}^{+}{ }_{3}$ adsorption sites.

At $\mathrm{pHs}$ of 11 and 13, $A R S^{3-}$ molecules at first interacted with $-\mathrm{NH}^{+}{ }_{3}$ and then $-\mathrm{NH}_{2}$ adsorption sites. At $\mathrm{pH}$ of $14, A R S^{3-}$ molecules interacted with $-\mathrm{NH}_{2}$ adsorption sites only. Different types of ARS molecules in acidic and alkaline media interacted with GO/PAMAM adsorption sites through their sulfonate head.

By using GO/PAMAM, several dyes including MB, AO, Th, PY, MEB and JG were separated from their mixtures with ARS at $\mathrm{pH}$ of 2 . Our extensive study illustrated that used adsorbent was regenerated completely and effi- ciently using ethylenediamine at ambient temperature.

Furthermore, GO/PAMAM can be used to selectively remove ARS from dye mixtures at $\mathrm{pH}$ of 2 . The finding could be beneficial to fabricate photochemical and electrochemical sensors.

\section{References}

1. M. F. Hamoda, I. Al-Ghusain, N. Z. Al-Mutairi, Desalination, 2004, 164, 203-211. DOI:10.1016/S0011-9164(04)00189-4

2. O. Tunay, E. Erdeml, N. Işık Kabdaşlı, T. Olmez, Environ. Technol., 2008, 29, 1045-1051.

DOI:10.1080/09593330802175823

3. G. Al-Enezi, M. Hamoda, N. Fawzi, J. Environ. Sci. Health A, 2004, 39, 455-464. DOI:10.1081/ESE-120027536

4. R. Hesnawi, K. Dahmani, A. Al-Swayah, S. Mohamed, S. A. Mohammed, Procedia Eng., 2014, 70, 810-814.

DOI:10.1016/j.proeng.2014.02.088

5. S. Palit, IJCA, 2012, 3, 302-305.

6. E. Nutiu, Proc. Technol., 2015, 19, 479-482.

DOI:10.1016/j.protcy.2015.02.068

7. F. Gorzin, M. M. Bahri Rasht Abadi, Adsorpt. Sci. Technol., 2017, 36, 149-169. DOI:10.1177/0263617416686976

8. T. Erban, J. Hubert, J. Insect Sci., 2010, 10, 1-12. DOI:10.1673/031.010.4201

9. J. Šíma, P. Hasal, Chem. Eng. Trans., 2013, 32, 79-84.

10. J. H. Miller, J. L. Kotenko, Stain Technol., 1987, 62, 237-245. DOI:10.3109/10520298709108001

11. M. S. Raghu, K. Basavaiah, K. N. Prashanth, K. B. Vinay, ISRN Spectroscopy, 2012, Article ID 648510.

DOI: $10.5402 / 2012 / 648510$

12. M. Fayazi, M. Ghanei-Motlagh, M. A. Taher, Mater. Sci. Semicond. Process., 2015, 40, 35-43.

DOI:10.1016/j.mssp.2015.06.044

13. D. Li, Q. Liu, S. Ma, Z. Chang, L. Zhang, Adsorpt. Sci. Technol., 2011, 29, 289-300. DOI:10.1260/0263-6174.29.3.289

14. L. Fan, Y. Zhang, X. Li, C. Luo, F. Lu, H. Qiu, Colloids Surf. B: Biointerfaces, 2012, 91, 250-257.

DOI:10.1016/j.colsurfb.2011.11.014

15. R. K. Gautam, P. K. Gautam, M.C. Chattopadhyaya, S. Banerjee, J. D. Pandey, Proc. Natl. Acad. Sci., India, Sect. A Phys. Sci., 2014, 84, 495-504. DOI:10.1007/s40010-014-0154-4

16. P. B. Wagh, V. S. Shrivastava, J. Sci. Res. Rep., 2014, 3, $2197-$ 2215. DOI:10.9734/JSRR/2014/8005

17. F. Fu, G. Ziwei, L. Gao, D. Li, Ind. Eng. Chem. Res., 2011, 50, 9712-9717. DOI:10.1021/ie200524b

18. S. Gao, W. Zhang, Adsorpt. Sci. Technol., 2019, 37, 185-204. DOI:10.1177/0263617418819164

19. M. Aissat, S. Hamouda, N. Benhadria, R. Chellali, N. Bettahar, AIP conference proceedings 1968, 2018, ID.020005.

20. H. V. Jadhava, S. M. Khetre, S. R. Bamane, Der Chemica Sinica, 2011, 2, 68-75.

21. M. Jamshidi, M. Ghaedi, K. Dashtian, S. Hajati, A. Bazrafshan, RSC Adv., 2015, 5, 59522-59532.

DOI:10.1039/C5RA10981G 
22. J. Zolgharnein, Z. Choghaei, M. Bagtash, S. Feshki, M. Rastgordani, P. Zolghadrian, Desalin. Water Treat., 2016, 57, 27672-27685.

23. O. Ali, S. Mohamed, Turk. J. Chem., 2017, 41, 967-986. DOI:10.3906/kim-1703-72

24. F. Zhang, B. Wang, S. He, R. Man, J. Chem. Eng. Data, 2014, 59, 1719-1726. DOI:10.1021/je500219e

25. Q. C. Compton, D. A. Dikin, K. W. Putz, L. C. Brinson, S. T. Nguyen, Adv. Mater., 2010, 22, 892-896.

DOI:10.1002/adma.200902069

26. M. Rafi, B. Samiey, C-H Cheng, Materials, 2018, 11, 496. DOI: $10.3390 / \mathrm{ma} 11040496$

27. K. S. W. Sing, D. H. Everett, R. A. W. Haul, L. Moscou, R. A. Pierotti, J. Rouquerol, T. Siemieniewska, Pure Appl. Chem., 1985, 57, 603-619.

28. R. M. Silverstein, G. C. Bassler, T. C. Morrill: Spectrometric Identification of Organic Compounds. Fourth Edition, John Wiley and Sons, New York, 1981.

29. Y. Piao, T. Wu, B. Chen, Ind. Eng. Chem. Res., 2016, 55, 61136121. DOI:10.1021/acs.iecr.6b00947

30. C. Wang, Y. Duan, N. S. Zacharia, B. D. Vogt, Soft Matter, 2017, 13, 1161-1170. DOI:10.1039/C6SM02439D

31. H. Gunzlr, H. U. Gremlich: IR Spectroscopy: An Introduction, Weinheim, Wiley-VCH, 2002.

32. B. Samiey, S. Golestan, Cent. Eur. J. Chem., 2010, 8, 361-369. DOI:10.2478/s11532-009-0135-7

33. B. Samiey, S. Abdollahi Jonaghani, J. Pollut. Eff. Cont., 2015. DOI:10.4172/2375-4397.1000139

34. I. Langmuir, J. Am. Chem. Soc., 1918, 40, 1361-1403. DOI: $10.1021 / \mathrm{ja} 02242 \mathrm{a} 004$

35. M. Boudart, G. Djega-Mariadassou: Kinetics of Heterogeneous Catalytic Reactions. Princeton University Press, New Jersy, 1984. DOI:10.1515/9781400853335
36. T. Sekine, T., Nakatani, K., Langmuir, 2002, 18, 694-697. DOI: $10.1021 /$ la0110500

37. B. Samiey, A. Dadkhah Tehrani, JCCS, 2015, 62, 149-162. DOI:10.1002/jccs.201400093

38. N. Safar Beyranvand, B. Samiey, A. Dadkhah Tehrani, Acta Chim. Slov., 2019, 66, 443-454. DOI:10.17344/acsi.2018.4920

39. J. Ghasemi, S. Lotfi, M. Safaeian, A. Niazi, M. M. Ardakani, M. Noroozi, J. Chem. Eng. Data., 2006, 51, 1530-1535. DOI:10.1021/je050535d

40. J. Ghasemi, A. Niazi, G. Westman, M. Kubista, Talanta, 2004, 62, 835-841. DOI:10.1016/j.talanta.2003.10.003

41. A. Córdoba, I. Magario, M. L. Ferreira, J. Mol. Catal. A-Chem., 2012, 355, 44-60. DOI:10.1016/j.molcata.2011.12.011

42. P. K. Maiti, T. Çağin, S-T Lin, W. A. Goddard, Macromolecules, 2005, 38, 979-991. DOI:10.1021/ma0491681

43. P. Nuengmatcha, R. Mahachai, S. Chanthai, Orient. J. Chem., 2016, 32, 1399-1410. DOI:10.13005/ojc/320314

44. Y. Guo, J. Deng, J. Zhu, C. Zhou, X. Zhou, R. Bai, RSC Advances, 2016, 6, 39762-39773. DOI:10.1039/C6RA03423C

45. R. W. Sabins: Handbook of Biological Dyes and Stains: Synthesis and Industrial Applications, John Wiley \& Sons, Inc., New Jersey, 2010.

46. M. I. Chaudhari, S. A. Holleran, H. S. Ashbaugh, L. R. Pratt, PNAS, 2013, 110, 20557-20562.

DOI:10.1073/pnas.1312458110

47. S. Lüdemann, R. Abseher, H. Schreiber, O. Steinhauser, J. Am. Chem. Soc., 1997, 119, 4206-4213. DOI:10.1021/ja953439d

48. D. W. Kimmel, G. LeBlanc, M. E. Meschievitz, D. E. Cliffel, Anal. Chem., 2012, 842, 685-707. DOI:10.1021/ac202878q

49. F. Li, J. Peng, Q. Zheng, X. Guo, H. Tang, S. Yao, Anal. Chem., 2015, 879, 4806-4813.

50. Z. Wang, N. Zhong, M. Chen, H. Chang, D. Zhong, Y. Wu, H. Liu, X. Xin, M. Zhao, B. Tang, T. Song, S. Shi, Applied Optics, 2019, 58, 2091-2099. DOI:10.1364/AO.58.002091

\section{Povzetek}

Preučevana je adsorpcija alizarin rdeče S (ARS) na grafen oksid/poli(amidoamin) (GO/PAMAM) glede na različne začetne koncentracije ARS, temperaturo, $\mathrm{pH}$ vrednosti, hitrost mešanja in kontaktni čas. Adsorpcijska mesta GO/ PAMAM so bile fenolne skupine $-\mathrm{OH}(\mathrm{Ph}) \mathrm{GO}$ in aminske skupine $\left(-\mathrm{NH}_{2},-\mathrm{NH}_{3}^{+}\right.$in $\left.-\mathrm{NHR}^{+}{ }_{2}\right)$ PAMAM dendrimernih enot GO/PAMAM. Pri pH vrednosti 2 in temperaturi $318 \mathrm{~K}$ je bila dosežena maksimalna kapaciteta $\left(q_{e, \max }\right)$ adsorbenta, ki je znašala $1275.2 \mathrm{mg} \mathrm{g}^{-1}$ in predstavlja eno najvišjih kapacitet opisanih v literaturi. Zato lahko smatramo, da deluje GO/PAMAM kot superadsorbent za ARS. V začetni fazi je adsorpcija kontrolirana $\mathrm{z}$ reakcijo $\left(\mathrm{E}_{\mathrm{a}}=114.5 \mathrm{~kJ} \mathrm{~mol}^{-1}\right)$ in se $A R S^{-}$molekule adsorbirajo na $P h$ mesta. Kasnejša adsorpcija na preostala adsorpcijska mesta pa je difuzijsko omejena. V bazičnem okolju smo identificirali dve drugi obliki ARS molekul, ki so se adsorbirale na $\mathrm{Ph}$ in $-\mathrm{NH}^{+}{ }_{3}$ mesta. Nadaljnje povečevanje bazičnosti raztopine se je odrazilo v nižanju števila adsorpcijskih mest in posledično nižanju adsorpcijske kapacitete $\left(q_{e, \max }\right)$. Poleg tega smo pri $\mathrm{pH}$ vrednosti 2 lahko s pomočjo GO/PAMAM ločili ARS molekule od molekul metilensko modrega, (MB), tionina (Th), pironina Y (PY), akridin oranžnega (AO), metil modrega (MEB) in janus zelenega (JG). 